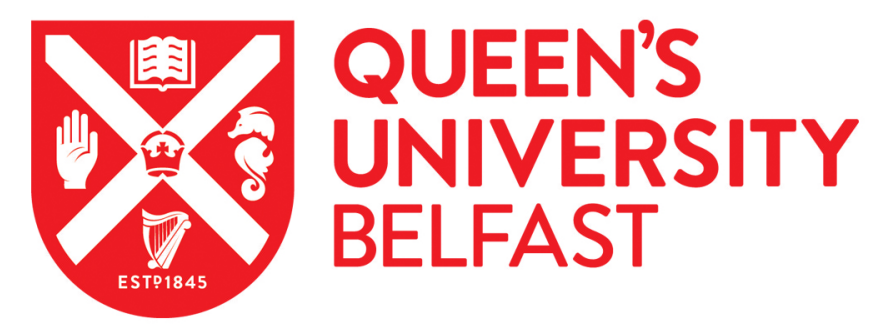

\title{
Contingent Employment and Labour Market Pathways: Bridge or Trap?
}

McVicar, D., Wooden, M., Lass, I., \& Fok, Y-K. (2018). Contingent Employment and Labour Market Pathways: Bridge or Trap? European Sociological Review. https://doi.org/10.1093/esr/jcy045

\author{
Published in: \\ European Sociological Review
}

\section{Document Version:}

Peer reviewed version

\section{Queen's University Belfast - Research Portal:}

Link to publication record in Queen's University Belfast Research Portal

\section{Publisher rights}

Copyright 2018 Wiley. This work is made available online in accordance with the publisher's policies. Please refer to any applicable terms of use of the publisher.

\section{General rights}

Copyright for the publications made accessible via the Queen's University Belfast Research Portal is retained by the author(s) and / or other copyright owners and it is a condition of accessing these publications that users recognise and abide by the legal requirements associated with these rights.

Take down policy

The Research Portal is Queen's institutional repository that provides access to Queen's research output. Every effort has been made to ensure that content in the Research Portal does not infringe any person's rights, or applicable UK laws. If you discover content in the Research Portal that you believe breaches copyright or violates any law, please contact openaccess@qub.ac.uk. 


\title{
Contingent Employment and Labour Market Pathways: Bridge or Trap?
}

\author{
Duncan McVicar \\ Queen's Management School, Queen's University Belfast \\ Mark Wooden \\ Melbourne Institute of Applied Economic \& Social Research, University of Melbourne \\ Inga Lass \\ Melbourne Institute of Applied Economic \& Social Research, University of Melbourne \\ Yin-King Fok \\ Melbourne Institute of Applied Economic \& Social Research, University of Melbourne
}

Keywords: casual employment; contingent employment; temporary employment; pathways; segmented labour markets; sequence analysis

Corresponding author: Mark Wooden, Melbourne Institute of Applied Economic and Social Research (Level 5, FBE Bldg, 111 Barry St), University of Melbourne VIC 3010, Australia. Email: m.wooden@unimelb.edu.au

Acknowledgements: This research was supported under the Australian Research Council's Discovery Projects funding scheme (project \# DP160103171). It uses unit-record data from the Household, Income and Labour Dynamics in Australia (HILDA) Survey. The HILDA Project was initiated and is funded by the Australian Government Department of Social Services (DSS) and is managed by the Melbourne Institute of Applied Economic and Social Research (Melbourne Institute). The findings and views reported in this paper, however, are those of the authors and should not be attributed to either DSS or the Melbourne Institute. 


\begin{abstract}
The debate over whether contingent (and typically more precarious) employment acts as a bridge to permanent employment, or as a trap, has tended to focus on transitions rather than longer-run pathways. This approach cannot accurately identify indirect pathways from contingent to permanent employment, nor "trap" pathways involving short spells in other states. It also fails to distinguish between those experiencing contingent employment as a "blip" and those with longer spells. This article employs a different approach involving sequence analysis. Exploiting longitudinal data for Australia, evidence for the co-existence of pathways that correspond to "bridge" and "trap" characterisations of contingent employment is found. Further, in the case of casual employment - the most common form of contingent employment in Australia - these two types of labour market pathways are roughly equally prevalent, although for women and those with low educational attainment "traps" are more likely than "bridges".
\end{abstract}




\section{Introduction}

Recent years have seen increased interest among researchers and policy-makers in the changing nature of work, and especially the role played by fixed-term, casual and other forms of contingent employment. This has been driven by two related concerns. First, it is widely believed that temporary (or fixed-term contract jobs; i.e., jobs with a predetermined end date) and casual jobs (which can be terminated at any time without notice) are accounting for a growing share of total employment, usually argued to reflect employer responses to rising global economic competition and a loosening of regulations governing employment security (e.g., Di Prete et al., 2006; Kalleberg, 2009; Prosser, 2016). Second, contingent employment is typically equated with poor-quality jobs (e.g., Kalleberg et al., 2000; McGovern et al., 2004; Nienhüser and Matiaske, 2006; OECD, 2014).

But as others have pointed out (e.g., Booth et al., 2002; Gash, 2008; Korpi and Levin, 2001), how concerned we should be about the incidence of contingent employment depends on the extent to which such employment provides a bridge to ongoing employment in the future. If contingent jobs typically do not lead to more secure permanent jobs (i.e., if the dominant labour market pathway for workers in contingent employment resembles a "trap"), then changes in employment regulations may lead to improvements in social welfare. Indeed, given contingent employment can cause postponement of major life events, such as buying a home, relationship formation and parenthood (e.g., Blossfeld et al., 2005; McGrath and Keister, 2008), persistently remaining in this state will likely entail long-lasting repercussions that extend well beyond the work sphere. Alternatively, if contingent employment typically provides a "bridge" to permanent employment, then arguments for interventions designed to limit the use of such contracts are more difficult to motivate as possible negative effects on worker well-being will likely be short-lasting. 
Existing evidence on this issue is mixed. Some research suggests that temporary jobs (and other forms of contingent employment) often serve as entry ports into more permanent jobs (e.g., Addison et al., 2015; Booth et al., 2002; Buddelmeyer and Wooden, 2011; de GraafZijl et al., 2011; Gash, 2008), while others conclude that the rate of transition between contingent and permanent jobs is relatively low (e.g., Esteban-Pretel et al., 2011; Güell and Petrongolo, 2007; Watson, 2013), that the risk of subsequently experiencing unemployment is higher among temporary job holders (e.g., Giesecke and Groß, 2003; Mooi-Reci and Dekker, 2015), and that in some situations, individuals might be better off waiting for a more secure job than accepting the first contingent employment opportunity (e.g., Barbieri and Scherer, 2009; Yu, 2012).

A key feature of this literature is its focus on single transitions between employment types or labour market states. This is restrictive given the complexity of employment patterns experienced by many, and especially by many in contingent employment. The overriding question - bridge or trap - is mostly not about single transitions (e.g., fixed-term to full-time permanent employment), but about more complex labour market pathways over extended periods of time (e.g., from casual to part-time permanent employment then back to casual, or from casual to full-time permanent employment via spells in part-time permanent or fixedterm employment). The analysis reported here thus differs from most previous research by exploiting longitudinal data, tracking a representative sample of working-age individuals in Australia over a 14-year window, to present a more holistic analysis of labour market pathways than is possible by focussing on single transitions. Further, the relative incidence of "bridge" and "trap" pathways is quantified. The study complements an earlier Canadian study, which takes a similar approach, but limited to a five-year window and with a sample restricted to those initially in temporary employment (Fuller and Stecy-Hildebrandt, 2015). 


\section{Contingent Employment and Workers' Employment Pathways}

\section{Employers’ Reasons for Offering Contingent Employment}

Permanent contracts form a crucial part of the traditional organisational career, where firms offer stable, secure employment and upward career mobility in exchange for their workers' loyalty and commitment. However, employers might also offer contingent contracts to some (or all) of their workers.

First, they may use contingent jobs to screen workers before offering them permanent contracts, with the prospect of a permanent contract also acting as an incentive for workers to provide effort (Faccini, 2014; Gebel and Giesecke, 2016). This is more likely for young workers and other labour market (re)entrants where match productivity is difficult to gauge in advance (Gebel and Giesecke, 2016; Barbieri and Cutuli, 2016). Furthermore, since productivity is often difficult to measure in high-skilled jobs, it follows that highly educated workers should be more likely to be subject to employer screening than lowly educated workers. Screening is also more likely where flexibilization at the margin has led to a big contrast in firms' labour adjustment costs between permanent and contingent workers (Barbieri and Scherer, 2009; Noelke, 2016).

Second, employers might have no intention of giving contingent workers a permanent contract, and instead use contingent contracts to: achieve flexibility (i.e., to reduce labour adjustment costs) when faced with uncertain or volatile product demand (Abraham, 1988; Rebitzer and Taylor, 1991); fill a genuinely short-term position (Booth et al., 2002); or avoid potentially disadvantageous aspects of employment law (Prosser, 2016), which is especially likely where there is a large difference in the level of regulatory protection provided to permanent and contingent workers. Unlike the screening mechanism, this seems less likely to predominantly affect young people; they are just one of several groups with relatively low labour market power, including women and those with comparatively low education levels, at 
risk of this kind of firm behaviour (Giesecke, 2009). The likely result is a segmented labour market, with one or more core sectors characterised by high quality and secure jobs (e.g., permanent contracts, high wages, training, career prospects) and one or more peripheral sectors characterised by low quality and insecure jobs (e.g., casual or fixed-term contracts, low wages, limited access to training, limited prospects for career progression) (Doeringer and Piore, 1971; Rebitzer and Taylor, 1991).

These employer strategies can be expected to have differing impacts on workers' employment pathways. If screening is the major reason for using contingent contracts, we expect to see a high degree of mobility between employment types. For those workers who are screened successfully, contingent work acts as a "stepping stone" or "bridge" into permanent employment. If, in contrast, employers mainly use contingent employment for flexibility reasons, and labour markets are segmented between contingent and permanent jobs, mobility between the core and periphery is expected to be limited. This might be because secondary sector workers are unable to acquire sufficient human capital to move into the primary sector, both because they may begin with lower skill levels on average (Olsthoorn, 2016) and because incentives to invest in training are less for both firms and workers than in the case of permanent jobs (McVicar et al., 2016). Secondary sector jobs may also be scarring if employers treat them as a signal of low productivity (Barbieri and Cutuli, 2016; Boyce et al., 2007). As a result, workers in the secondary sector might either become "trapped" in a series of contingent jobs or experience "churning" (i.e., a sequence of contingent employment and non-employment).

\section{Workers' Reasons for Accepting Contingent Employment}

Workers' employment careers have traditionally been viewed as evolving within the framework of the institutionalised life course, centred on waged labour and structured 
chronologically with the three phases of preparation, activity and retirement (Kohli, 2007). In this regime, work biographies are marked by continuous (full-time) employment, long job tenure, and upward career mobility (Kohli, 2007; Mayer, 2005). In line with this life course model, the literature typically finds that most workers prefer permanent employment and only accept contingent employment involuntarily for lack of alternative options (Giesecke, 2009; Kalleberg et al., 1997; Morris and Vekker, 2001).

Nevertheless, some workers might voluntarily choose contingent employment, depending on their personal circumstances and stage in the life course. Young workers, for example, might be willing to accept contingent positions to gather experience in different fields until they are sure about their career preferences (Booth et al., 2002). Many students acquire only general skills, and not vocationally specific skills. Vocational skills are instead mostly acquired on the job. The link between the type of qualification obtained and the type of job is thus often relatively weak, and young workers often undergo a period of high job mobility until a good job match is found (Mills and Blossfeld, 2013). Students might also be attracted to the flexibility in hours that may come with some forms of contingent employment. Overall, we expect to observe many young people in persistent contingent employment (while studying) or attempting to use contingent employment as a bridge to permanent employment (after graduation).

In contrast, older workers might use contingent employment as a bridge into retirement. In recent decades, the boundaries between work and retirement have become increasingly blurred as more workers remain employed beyond the eligibility age for old age pension (ABS, 2010; Wilkins and Wooden, 2014). Many workers also express preferences to switch to part-time employment - and most casual jobs are part-time jobs - before retiring (ABS, 2010). We therefore expect that older workers will be more likely to deliberately change into contingent employment. Further, given the relatively shorter remaining period available for 
employment, many older workers might not consider contingent contracts a significant disadvantage. For these workers we might see a pattern of phasing out of (permanent) employment into retirement by means of contingent jobs.

Women might also be disproportionately willing to accept contingent work. The standard work biography of continuous full-time employment is predominantly based on men's traditional experiences in the labour market. Recent decades, however, have seen an increase in women's, and especially mothers', participation in the labour force. Despite this, women continue to do the main share of housework and care (Craig and Mullan, 2009), and most women still interrupt their employment career around the time of child birth (Baxter, 2013). To balance the demands of work and family, women might seek, or at least be more willing to accept, contingent jobs (Hakim, 2006; Morris and Vekker, 2001), possibly resulting in a higher share of women with "trap" employment careers. There are also home-centred women who prefer not to work and only enter the labour market in times of economic necessity (Hakim, 2006). For these women, employment is planned to be only temporary, suggesting a pattern of churning into and out of (contingent) employment.

Of course, these groups - young people, older people, women - are also likely to be among those with the least bargaining power in the labour market, and a workers' capacity to avoid contingent employment is likely to vary depending on their personal resources, the household context and their employment history. Where workers already have a permanent contract, for example, they usually cannot be forced onto a contingent contract, suggesting a high degree of stability in permanent employment and the channelling of contingent employment towards labour market (re)entrants. In contrast, workers who have a history of contingent employment might become scarred, with potential future employers being reluctant to offer them permanent contracts. Scarring may be more likely for workers whom employers might typically expect to be in permanent employment; e.g., prime-age men 
(Mooi-Reci and Wooden, 2017). However, a history of contingent contracts might still be more advantageous than unemployment given workers accumulate work experience and can build networks with persons supporting their careers (Fuller and Stecy-Hildebrandt, 2015). Further, where workers are seeking a first or a new job, they may feel more pressured to accept a contingent job if they have: (i) limited choice between jobs and thus low bargaining power (which we expect to be particularly likely for low-skilled workers, migrants and workers with health conditions); or (ii) financial responsibility for other household members (such as children).

\section{The Australian Context}

By international standards, the proportion of workers in contingent forms of employment is high in Australia. Pooled data from the Household, Income and Labour Dynamics in Australia (HILDA) Survey (2001-2014), for example, indicate that on average, $14 \%$ of the Australian working-age population (or $22.7 \%$ of all employees) were employed on a casual basis, and a further $5.7 \%$ (or $9.3 \%$ of employees) were employed on a fixed-term contract (see Table 1). Casual employment is salient for all demographic groups, but its incidence is particularly pronounced among young people (31\% of all persons aged under 25 years) and among women (16\% vs. $12 \%$ among men). These patterns are consistent with those found for fixed-term and agency employment in many European countries (see Barbieri, 2009). The balance between casual and fixed-term employment, however, is atypical. Indeed, Australia is distinctive among developed nations for its high rate of casual employment. While concerns have recently been expressed in Europe about the emergence of new forms of employment, including casual work (e.g., Eurofound, 2015), such jobs still account for a relatively small faction of the workforce in most European countries. ${ }^{1}$ 
Deregulation of the labour market for fixed-term and other contingent jobs while maintaining existing levels of employment protection legislation (EPL) for permanent jobs (flexibilization at the margin) is widely seen as a key driving force behind the growth of contingent employment in Europe (e.g., Barbieri and Scherer, 2009; Noelke, 2016). In most respects, both casual and fixed-term contracts are also loosely regulated in Australia (OECD, 2013; Stewart et al., 2016). Employers generally do not need to state specific reasons to use these types of contracts, and there is no maximum cumulated duration of such contracts prescribed by law. Casual and fixed-term employment contracts are, however, very different, with the former providing employers with much more flexibility. Most obviously, casual workers can usually be dismissed at any time ${ }^{2}$, while fixed-term contract workers generally have an expectation that they will be employed until the end of their contract. Casual contracts can also be renewed frequently, whereas successive fixed-term contracts might be considered as ongoing employment by an industrial tribunal. And while employers of casual workers do not need to commit to a specific number of days or hours to be worked when hiring, fixed-term contracts will usually contain such information. Casual employment in Australia is also typically associated with the absence of entitlement to paid leave and paid public holidays; this is not true of fixed-term contracts. On the other hand, to compensate for lack of leave entitlements and greater job insecurity, employers are required to pay casual employees a pay premium (currently $25 \%$ ) on top of minimum rates of hourly pay for permanent workers specified in industry awards.

Workers' employment pathways may be affected not only by the absolute level of EPL for contingent contracts, but by the size of the gap in EPL between permanent and contingent workers, with large EPL gaps indicating institutionally driven labour market segmentation (Barbieri and Cutuli, 2016). While levels of EPL for permanent workers in Australia are not 
high by OECD standards, Australia still exhibits a comparatively large EPL gap between permanent and contingent workers (OECD, 2013).

Further, the generosity, conditionality and coverage of unemployment insurance and welfare more generally is also relatively modest (Esping-Andersen 1999), incentivising unemployed workers to quickly take up new (and potentially contingent) employment.

Finally, government policy provides incentives for older workers to keep working beyond conventional retirement ages. The state-funded Age Pension is a modest, flat-rate and meanstested payment. And while Australia also has an additional superannuation scheme for accumulating retirement income that is funded by employer contributions, these contributions only became mandatory in 1992 and the level of contributions required has been low (gradually rising from an initial $3 \%$ of salaries to $9.5 \%$ by 2014). This combination of a low flat-rate, means-tested pension and a slowly developing compulsory superannuation system is reflected in net income replacement rates in retirement that are relatively low - just $43 \%$, compared to an OECD average of 63\% (OECD 2017). These conditions suggest that many workers in Australia have an incentive to continue working beyond the pension age and may, in turn, use part-time and casual employment to facilitate a gradual withdrawal from paid employment. Indeed, the Australian Government has introduced measures specifically designed to encourage gradual retirement, such as the introduction in 2005 of Transition to Retirement Pensions.

\section{Hypotheses}

These demand and supply-side mechanisms suggest the following testable hypotheses:

1) Contingent employment will be embedded in three different types of employment pathways. These are: (i) workers moving from contingent employment to permanent employment (bridge); (ii) workers remaining persistently in contingent employment or 
churning between contingent employment and other states including non-employment (trap); and (iii) workers changing from permanent to contingent employment (phasing out).

Screening, job shopping or human capital accumulation suggest bridge pathways. Segmented labour markets, minimising labour adjustment costs and preferences for flexibility on the part of some workers suggest trap pathways. The changing nature of retirement suggests phasing out pathways.

2) Specific subgroups of workers will be particularly likely to be found in each of these contingent employment pathways. Young people will be more likely than other age groups to be found in (i) contingent trap and, particularly, (ii) bridge pathways; women (especially carers) will be more likely than men to be found in (iii) bridge and, particularly, (iv) trap pathways; (v) those with low education levels and other signals of potentially low productivity (e.g., work-limiting health conditions) will be more likely than those with high educational level or other signs of potentially high productivity to be found in trap pathways; and (vi) older workers will be more likely than other age groups to be found in phasing-out pathways.

Screening, job-shopping or human capital accumulation is most likely among young people (entrants) and mothers (re-entrants), suggesting bridge pathways. Being on the wrong side of a segmented labour market is most likely for young people, women, the low-skilled, those with work-limiting health conditions, and the 'scarred', suggesting trap pathways. A preference for flexibility is most likely among young people, carers, those with work-limiting ill-health, suggesting trap pathways. A similar preference among older people suggests phasing-out pathways. 
3) Given the differences in legislative requirements with respect to casual and fixed-term contracts in Australia, casual employment is expected to result more often in trap pathways than fixed-term contract employment.

Employers seeking to minimise labour adjustment costs are likely to hire workers on casual contracts with limited expectation of a route to a permanent contract; i.e., casual trap. Many workers accepting casual contracts may have little choice or may prefer flexibility, again suggesting casual traps. Employers seeking to screen workers are likely to hire workers on fixed-term contracts; i.e., fixed-term bridge pathways.

\section{Data}

\section{Sample}

The data come from the HILDA Survey, a longitudinal study that has been following members of a nationally representative sample of Australian households since 2001 (Watson and Wooden, 2012). The initial sample of respondents comprised 13,969 individuals, aged 15 years or older, from 7,682 households. A population refreshment sample was introduced in wave 11 (2011), which added a further 2,153 responding households. Sample sizes vary each survey wave reflecting deaths, non-response and changes in household composition (interviews are sought with all persons aged 15 years or older who are co-residing with an original sample member). Consistently high response rates mean that, even without the refreshment sample, the sample size in wave $14(13,633)$ was very similar to that in wave 1.

Data from waves 1 to 14 (2001 to 2014) are used. Since our interest is in long-run labour market pathways, only individuals who are observed for at least ten waves are retained. (This minimum wave requirement is varied in a sensitivity analysis.) Further, to focus on labour market pathways among working-age individuals, only those who are aged 59 years or less in the first wave in which they are observed are retained. The maximum age at which an 
individual can be observed in the sample is therefore 72 years. This provides an unbalanced sample comprising 118,828 observations from 8,694 individuals.

The HILDA Survey collects extensive information about individuals' labour market state and, for those in work, the job held (including the nature of the employment contract), at the time of each annual interview. Detailed information is also collected on individual and household socio-economic characteristics. Table 2 presents sample means for the subset of variables used in this analysis. Selection of variables reflects factors cited by Kalleberg (2009) as being important in vulnerability to precarious work and frequency of use in existing studies of contingent employment using HILDA Survey data.

As reported in a Supplementary Appendix (Tables S1 and S2), the characteristics of the analysis sample diverge slightly from that of the full, pooled HILDA Survey sample for persons aged 15 to 72 years. The analysis sample is more concentrated in the 25-59 years age range because new survey members, who are predominantly young, can only enter the sample prior to wave 5 (given the requirement to be observed for at least ten waves), and because we restrict to those aged 59 years and under in the first observed wave. Further, as the analysis sample ages over the observation period, the proportion in casual employment also falls relative to those in the corresponding waves for the full sample (as shown in Table S2). This is to be expected in a longitudinal sample if there is a "bridge" phenomenon for at least some casual workers, although it may also reflect non-random attrition.

\section{Classifying Labour Market State and Employment Type}

At each observed wave, respondents are classified into one of six mutually exclusive and exhaustive labour market categories. The sample is first divided into two groups based on their labour force status: the employed and the non-employed (pooling the unemployed and the inactive). ${ }^{3}$ All respondents who were employed at any time in the week prior to interview 
are asked whether, in their main job, they worked for an employer for wages or salary (employees), in their own business (the self-employed), or without pay in a family business. Employees are then asked to choose one among four categories that best describes their current employment contract in their main job: (i) employed on a permanent or ongoing basis; (ii) employed on a fixed-term contract; (iii) employed on a casual basis; or (iv) employed under some other arrangement. The answers to (i)-(iii) are used to define permanent, fixed-term and casual employment respectively. The self-employed, those working unpaid in a family business, and employees in category (iv), are aggregated into a catch-all 'other employed' category. Those employed on a permanent contract are then subdivided into those employed full-time (35 hours or more per week) and those employed part-time. To keep the number of states manageable a similar distinction is not made for the remaining employed categories.

To account for potentially non-random attrition from the survey, a non-response state is also created. Waves in which an individual is out of scope are treated as missing observations. This means there is some variation in the length of the pathways analysed, though all are at least 10 years in duration (and most are 14 years in duration).

\section{Transitions between Labour Market States}

Table 3 shows the average year-to-year transitions between labour market states. In most cases the majority of persons in a particular state at time $t$ are in the same state at time $t+1$ (the exceptions are fixed-term employment and non-response). Looking at the off-diagonals, however, the five most common transitions are, in descending order: from not employed to casual; from fixed-term to full-time permanent; from full-time permanent to fixed-term; from casual to not employed; and from casual to full-time permanent. Fixed-term employment is the most common entry point to full-time permanent employment. Casual employment is 
both the most common entry point to, and exit point from, non-employment, and the second most common entry point to full-time permanent employment. In short, and in line with a previous analysis of these data (Buddelmeyer and Wooden, 2011), transitions are observed that appear consistent with fixed-term and casual employment acting as a bridge into permanent employment, but also transitions in the other direction; transitions between contingent (particularly casual) employment and non-employment in both directions, and persistence in contingent employment. What such an analysis does not reveal, however, is whether the individuals making the initial transition from not employed to casual employment subsequently go on to permanent or other forms of employment (i.e., casual employment as a bridge), or remain casual or cycle between casual employment and nonemployment (casual employment as a trap). Similarly, it is unclear whether those moving from fixed-term to full-time permanent employment remain in that state or churn back and forth between different forms of employment.

\section{A Typology of Labour Market Pathways}

\section{Sequence Analysis}

In common with the growing literature which applies sequence analysis to labour market data (e.g., Brzinsky-Fay, 2007; Fuller and Stecy-Hildebrandt, 2015; McVicar and AnyadikeDanes, 2002), each individual's longitudinal record of labour market states is treated as a string. It is these strings - sequences - that capture labour market pathways, and in what follows the sequence, rather than individual elements of sequences (i.e., observations for particular waves), is the unit of analysis. The most common sequence - followed by just $5.5 \%$ of the sample - is a labour market pathway consisting of 14 waves of full-time permanent employment. But there is a myriad of pathways, and two thirds of sample members follow unique sequences. (The most frequent sequences in the sample are listed in 
Supplementary Appendix Table S3.) Many of these unique sequences are similar, with common ordering of labour market states but different durations in one or more of these states, or with labour market states varying in only a small number of waves. To make further progress in describing the labour market pathways followed by the sample requires a method which first quantifies how similar different observed sequences are and then groups similar sequences into 'types'. Following the studies cited above, optimal matching $(\mathrm{OM})$ followed by cluster analysis is used for this purpose.

$\mathrm{OM}$ is an algorithmic approach to measuring the distance between two strings of categorical states by asking the question: "How could we turn one string into another with the least possible cost?" This cost is a measure of the minimum combination of elementary operations (substitutions, insertions, or deletions of sequence elements) required to achieve such a transformation. As is convention, substitution costs are defined as inversely proportional to transition probabilities in the data (see Supplementary Appendix Table S4 for the specific values) and insertion/deletion (or indel) costs are specified high enough that indels are never used in place of a single substitution but may be used to align similar but misaligned sequences or to align sequences of different lengths (Brzinsky-Fay et al., 2006). The resulting output from the $\mathrm{OM}$ analysis is a 6,426 by 6,425 matrix containing the distances between every pair of observed sequences in the data. ${ }^{4}$

\section{Cluster Analysis and Classifying Labour Market Pathways}

The distance matrix from the OM analysis forms the input for a cluster analysis of labour market pathways from which a typology is constructed. Following the convention in the literature, Ward's hierarchical agglomerative method, which works from the bottom up by combining 'similar' sequences, proceeding until all the observations belong to the same group, is used. Rather than adopt mechanical stopping rules to 'determine' the number of 
clusters, in what follows we describe a typology based on seven clusters, which is the smallest number of clusters that differentiates between (groups separately) casual workers who, by and large, go on to full-time permanent employment and casual workers who remain in casual employment or churn in and out of casual employment. (For the dendogram underlying this cluster solution, see Supplementary Appendix Figure S1.)

Table 4 labels the clusters in the resulting typology and presents summary information on their labour market state composition. There are two clusters dominated by full-time permanent employment: one - the largest cluster - groups together those who are consistently in full-time permanent employment (Cluster 1), while the other groups together those exiting from full-time permanent employment (Cluster 2). Casual workers are found across all seven clusters but are particularly concentrated in two contrasting clusters: one that groups together casual workers who mainly go on to full-time permanent employment (Cluster 3) and one that groups together casual workers who remain persistently in casual employment or churn in and out of casual employment (Cluster 4). These two clusters are of similar size, each containing around $7.5 \%$ of the sample. There are distinct clusters for pathways dominated by part-time permanent employment (Cluster 5) and by other employment (Cluster 6). Finally, there is a distinct cluster dominated by non-employment (Cluster 7). Because transitions between fixed-term and full-time permanent employment are relatively common (and therefore substitution costs are relatively low), there is no distinct fixed-term employment cluster at this level of aggregation. The highest density of fixed-term employment, however, is in cluster 1, most commonly combined with one or more spells in full-time permanent employment. A graphical representation of the clusters - sequence index plots - is provided in Figure S2 in the Supplementary Appendix.

Table 4 also reveals that the incidence of non-response is low (just $3.6 \%$ of observations). Even more importantly, the incidence of non-response varies little across the different 
clusters. This is a welcome finding given fears that particular labour market pathways (those involving considerable employment instability) might be associated with higher levels of survey non-response, which in turn would impart biases.

Cluster (pathway type) 1: persistent full-time permanent $(n=2,315)$. The largest cluster groups together pathways that are dominated by persistent full-time permanent employment, which accounts for $80.6 \%$ of all wave-individual observations in the cluster. The modal sequence is full-time permanent employment throughout. Casual, permanent part-time, other employment and non-employment are all virtually absent from this cluster. Fixed-term employment is there in proportion to the overall sample, typically in the form of a short spell followed directly by permanent full-time employment.

Cluster 2: exits from full-time permanent employment and churn $(n=1,132)$. Almost all $(96.6 \%)$ individuals in this cluster have at least one spell (of varying length) in full-time permanent employment. These are preceded or followed by spells in all five other labour market states, and often churning between other states, with not working being the next most prevalent state and the most common destination state in the latter waves. This is the cluster with the highest concentration of fixed-term employment, most commonly followed by and/or preceded by full-time permanent employment, but again tending towards nonemployment in the latter waves. The modal sequence type is a single spell of full-time permanent employment followed by a single spell of non-employment.

Cluster 3: casual to full-time permanent $(n=672)$. This cluster is dominated by pathways from casual employment to permanent full-time employment, in some cases with a short intervening state in another type of employment or in non-employment, and by pathways from non-employment to permanent full-time employment via a spell in casual employment. It accounts for $7.7 \%$ of the total sample and groups together individuals for whom casual employment acts as a bridge or stepping stone to permanent full-time employment. There is, 
therefore, evidence from a pathways perspective that is consistent with the argument in the transitions literature that contingent jobs - in this case, casual jobs - can serve as entry ports into more permanent jobs. However, and very different to the literature, such transitions are shown to be both direct and indirect, casual 'bridge' spells are often quite long, and the fulltime permanent employment destination tends to persist until the point of right-censoring.

Cluster 4: persistent casual and casual churn $(n=651)$. Labour market pathways in this cluster are dominated by casual employment, which accounts for over half the total waveindividual observations. Spells of casual employment tend to be relatively long or, where shorter, recurring. All other labour market states can be found within the casual churn pathways, or following long spells of casual employment, but non-employment is most common. The modal sequence type is casual employment throughout. In other words, this cluster, which accounts for $7.5 \%$ of the total sample, groups together individuals who are persistently casual or churning in and out of casual employment; i.e., it closely corresponds to the view of casual employment as a 'trap'. In contrast to the transitions approach, however, the pathways approach helps to demonstrate the churn in and out of casual employment and other labour market states in this cluster.

Cluster 5: part-time permanent employment $(n=704)$. Pathways in this cluster are dominated by part-time permanent employment, which accounts for just over half the total wave-individual observations. There is a mix of long spells and shorter spells, with some pathways showing churn into and out of part-time permanent employment. Spells of parttime permanent employment often follow short spells in casual, full-time permanent employment and non-employment. There are also examples of short spells of casual employment acting as a bridge from non-employment to permanent part-time employment. The most common destination state following a spell in part-time employment here is nonemployment (the modal sequence). 
Cluster 6: other employed $(n=1,325)$. This cluster is dominated by other employment (predominantly self-employment). In most cases, spells in other employment are long - the modal sequence type is other employment throughout - but they are often preceded by spells in other labour market states, most commonly permanent full-time employment. There are very few transitions from other employment into states other than non-employment or nonresponse. In Australia, once you make the transition to self-employment you are relatively unlikely to transition back into other forms of employment.

Cluster 7: not working $(n=1,895)$. The second largest cluster is dominated by not working - the modal sequence is non-employment throughout - with all other labour market states under-represented. The partial exception to this is casual employment, which occurs in just under half the pathways as a single short spell preceded and/or followed by non-employment. In simple transitions-focussed studies this would be indistinguishable from the transitions between casual employment and non-employment found in cluster 4.

Returning to our hypotheses, we indeed see pathways consistent with those suggested by hypothesis 1: casual bridge pathways predominantly in cluster 3 and fixed-term bridge pathways in clusters 1 and 2; casual trap pathways in cluster 4; and phasing out pathways particularly, but not only, in cluster 2. We also see much clearer evidence of casual trap pathways than of fixed-term trap pathways, consistent with hypothesis 3.

\section{Sensitivity Analysis and Extensions}

Further aggregating to six clusters merges the 'casual to full-time permanent' cluster with the 'exit from full-time permanent and churn' cluster, which obscures the differences between these pathway types. Stopping the agglomerative process earlier - selecting a higher number of clusters - retains a small fixed-term employment cluster $(n=171)$ that would otherwise merge with the 'exit from full-time permanent and churn' cluster. 
We also modified the sequence analysis and the sample in various ways to test the robustness of our cluster solution. Details of all sensitivity analyses are presented in the Supplementary Appendix. The matching and clustering exercise was repeated first with alternative substitution and indel costs (three different cases) (see Tables S5 and S6), then with three different sets of sample restrictions (dropping under 19s to omit those most likely to still be in full-time schooling, dropping over $55 \mathrm{~s}$ to omit those most likely to be retirees for all or most of the analysis period, and relaxing the requirement to be observed in $10+$ waves) (Table S7). In each of these six sensitivity analyses, agglomeration proceeds until arriving at the smallest number of clusters where both a 'casual bridge' and a 'casual trap' cluster are separately identified. This varies between seven and 13 clusters. But in all six cases the key conclusion remains the same; casual bridge and casual trap pathways appear similarly prevalent. $^{5}$

Further, because those in the two casual-dominated clusters spend comparatively more of the analysis period in full-time education (around $20 \%$ in each case compared to an overall analysis sample average of 6\%) the sizes of clusters in the existing typology are examined when those ever observed in full-time education in the first three or five waves are dropped (Table S8). In both cases both casual clusters fall in size, by slightly more for the casual bridge cluster than the casual trap cluster. Students are an important source of those following both types of pathway, and a particularly important source of those following casual bridge pathways; but not the only source.

We then repeated the analysis above for the sample split by gender (Table S9). Again, clear casual trap and casual bridge clusters, of similar sizes, are observed among both men and women. Bridging from casual to permanent employment, however, tends to take longer among women than men. Similarly, casual trap pathways tend to show even more persistent or recurring casual employment among women than among men. Also note that casual trap 
pathways among men, but not among women, are disproportionately found among the young. Finally, we repeated the analysis above for the sample restricted to those aged 35 years or under at first observed wave (also Table S9). Once again clear casual bridge and casual trap clusters, of similar sizes (albeit accounting for a larger proportion of the relevant sample), are observed. The key conclusion - that casual trap and casual bridge clusters co-exist in roughly similar proportions - holds not just for the full sample but across all these restricted samples.

\section{Who Follows What Pathway?}

The final step in the analysis is to describe how these clusters - from the main 7-cluster solution - map onto the rich set of individual and contextual characteristics listed in Table $2{ }^{6}$ (Supplementary Appendix Table S10 provides descriptive statistics for each of these characteristics disaggregated by cluster.) Because many of these observed characteristics are correlated with one another, a multivariate regression model for labour market pathway type is estimated. This enables the quantification of associations between pathways and selected characteristics holding all other (observable) factors constant. Given the unordered categorical nature of the dependent variable (the cluster), a multinomial logit model is employed. Results are presented, in Table 5, in both coefficient and relative risk ratio form. Discussion focuses on the casual trap and casual bridge clusters. ${ }^{7}$

Other (observable) things being equal, and compared to the reference pathway of persistent full-time permanent employment, the relative risk of following one or other of the casual pathways is higher for females, single persons and migrants from non-English speaking countries, and for those outside the 25-49 age range, with comparatively low qualification levels, with lower cognitive ability, with particular personality traits (more open to experience or less conscientious), with a long-term health condition or disability, with preschool or school-aged children, with less labour market experience, and in local labour 
markets with higher unemployment rates. These associations are mostly in accordance with expectations.

Of specific interest are those characteristics that are differentially associated with the two casual clusters; i.e., that disproportionately predict how likely an individual is to follow a casual trap pathway compared to a casual bridge pathway. The two standout characteristics in this respect are gender and education. Women are more than twice as likely as men to follow a casual bridge pathway but almost six times as likely to follow a casual trap pathway, consistent with hypotheses 2(iii) and 2(iv). Those that have not completed high school (i.e., Year 12) are twice as likely to follow a casual trap pathway as those that have (consistent with hypothesis $2(\mathrm{v}))$, but are no more likely to follow a casual bridge pathway. Other characteristics disproportionately associated with casual bridge but not casual trap pathways include being a migrant from a non-English speaking country and lack of labour market experience. Just as interesting are the characteristics that do not appear to substantially differentiate between the two clusters, which include age (inconsistent with hypothesis 2(ii)), having a long-term health condition (only weakly consistent with hypothesis $2(\mathrm{v})$ ), the presence of children, and the local unemployment rate.

In an extension designed to further capture possible demand-side factors - for which full results are presented in the Supplementary Appendix (Table S11) - we add variables for first observed sector of employment and first observed occupation for each individual, recognising that casual employment is concentrated in particular occupations and industries. ${ }^{8}$ Inclusion of these additional controls has little impact on the coefficients of the worker characteristics in the model. There are two exceptions, however. First, the effect of educational level on the likelihood of following a bridge or trap pathway compared to permanent full-time employment decreases in magnitude (but retains the same pattern), suggesting that education impacts on workers' employment pathways partly through the occupations and industries 
typically associated with different types of qualifications. Second, and for a similar reason, the impact of age diminishes (but again retains the same pattern).

Although our approach does not enable the acceptance or rejection of any particular underlying behavioural mechanism as driving these patterns, just as the co-existence of casual bridge and casual trap clusters is consistent with multiple such mechanisms operating simultaneously in the Australian labour market, so too are the patterns of who tends to follow what pathway. For example, the disproportionate concentration of migrants and those with low labour market experience in casual bridge pathways is consistent with the screening mechanism; the disproportionate concentration of women and those with low education in casual trap pathways is consistent with employers using such workers as a flexible buffer stock in a segmented labour market context; the disproportionate concentration of women in casual trap pathways is also consistent with a disproportionate preference for flexibility on the part of these workers.

\section{Discussion and Conclusion}

This paper shows that the standard work biography of continuous employment on a permanent contract is still highly prevalent in Australia. Yet, alongside this dominant traditional pattern, we see a second large group of workers with heterogeneous labour market pathways and great diversity in the ways in which contingent employment, and particularly casual employment, is embedded into them. Most importantly, the paper provides evidence of labour market pathways that correspond to both "bridge" and "trap" characterisations of contingent employment. While the first comprises pathways that lead either directly or indirectly from contingent employment into permanent full-time positions, the latter comprises both pathways of persistent contingent employment or churning into and out of contingent employment. Further, in the case of casual employment, bridge and trap pathways 
are found to be roughly equally prevalent. This finding is broadly in line with conclusions drawn with respect to temporary jobs in Canada by Fuller and Stecy-Hildebrandt (2015), the only previous published study that has adopted a pathways approach. That said, for some demographic groups - especially women and those with low educational attainment - casual "traps" are more likely than casual "bridges". In contrast, we do not find evidence of widespread use of casual or other forms of contingent employment to phase out of (permanent) employment into non-employment/retirement, although such pathways are observed. Casual traps are also more salient in Australia than fixed-term traps.

The co-existence of casual bridge and casual trap clusters, and the disproportionate concentration of migrants and those with little labour market experience in the former, and women and those with low education in the latter, suggests multiple mechanisms at work. These likely include screening and minimising labour adjustment costs on the part of employers, but also potentially preferences on the part of some workers. The co-existence of casual bridge and trap pathways also suggests caution when considering policy options for the regulation of such contracts; on the one hand, casual contracts exacerbate the risk of labour market segmentation and growing inequalities between different groups of workers, and on the other they offer a route to permanent employment for many and a flexible form of employment for others who may value that flexibility.

Although the HILDA Survey data on which this research relies has many desirable properties, the data are not without limitations. First, the sample tracked is not a cohort but instead combines individuals at different stages in the life course. Our conclusions are arguably more general as result. However, some interpretability is inevitably lost when grouping together pathways at different ends of the age spectrum, and when prior labour market history remains unobserved for many. 
Second, while the data are longitudinal they are still based on observations at discrete points in time. Employment status between the annual interviews is not known, and hence the sequences are constructed from incomplete histories.

Third, like all surveys, and especially panel surveys, we have the problem of missing data due to non-response. While we have presented evidence showing both that the incidence of missingness within our selected sample is relatively small and that our results are qualitatively unaffected by the selection choices we have made, we cannot entirely rule out the possibility of selection biases. In particular, non-response may be more likely among persons whose circumstances (including their employment circumstances) are frequently changing. If so, it is possible that we have understated the incidence of trap pathways.

Another limitation of our study is that we were unable to explicitly test the underlying mechanisms causing workers to end up in bridge or trap pathways. This task lies beyond the scope of the current study but is clearly of importance and something for future research. However, additional data will be required; for example, covering employee preferences for different employment contract types and the preferences of employers of those workers.

Whether contingent employment acts as a bridge or a trap is inherently a question about pathways and not single transitions. Yet, despite the availability in many countries of detailed longitudinal data tracking representative samples of workers over long periods, almost all the empirical literature examining this question takes a transitions approach. As a result, key questions - about the existence and relative prevalence of bridge and trap pathways, and about who follows what kind of pathway - remain largely unanswered. Our hope is that the pathways used here (and in the earlier work of Fuller and Stecy-Hildebrandt, 2015), will provide a model for future research exploring labour market transitions in other settings. 


\section{Notes}

${ }^{1}$ In the UK there has been growing concern about the rise in zero-hours contracts, which the UK Office for National Statistics (ONS) defines as contracts which do not guarantee a minimum number of hours (ONS, 2017). Labour Force Survey data, however, suggest that the proportion of British workers on such contracts in their main job peaked, in 2016, at just $2.9 \%$ (ONS, 2017).

${ }^{2}$ Casual employees who have worked for their employer on a regular and systematic basis for at least six months (or 12 months in small businesses), however, are provided legislative protection from unfair dismissal.

${ }^{3}$ We pool unemployment and inactivity for two reasons. First, the OM algorithm can struggle when there are too many categories, and given our focus is on different types of employment contract that is where disaggregating categories is most important. Second, hidden unemployment arguments point to a somewhat fuzzy dividing line between unemployment and inactivity.

${ }^{4}$ We used the Stata SQ ado files described in Brzinsky-Fay et al. (2006) for the OM analysis and Stata's clustermat command for cluster analysis.

${ }^{5}$ Although still prevalent, both types of pathway are less commonly observed in the sample when we drop under 19s.

${ }^{6}$ All covariates are time-constant and information is taken from the first valid measurement for each individual, except for educational attainment, which is taken from the last measurement given many of those at the younger end of the sample age range have yet to complete their education.

${ }^{7}$ Consistent with hypothesis 2(vi), older workers are disproportionately found in clusters 2 and 5 where phasing out pathways are most concentrated. 
${ }^{8}$ These variables are only defined for those observed in employment during the sample window so there are numerous missing values (addressed by adding an indicator for "never observed working" to the model). 


\section{References}

Abraham, K. G. (1988). Flexible staffing arrangements and employers' short-term adjustment strategies. In Hart, R. A. (Ed.), Employment, Unemployment and Labour Utilization. London: Unwin Hyman Press, pp. 288-311.

Addison, J. T., Cotti, C. D. and Surfield, C. J. (2015). Atypical jobs: stepping stones or dead ends? Evidence from the NLSY79. The Manchester School, 83, 17-55.

Australian Bureau of Statistics [ABS] (2010). Older people and the labour market. In Australian Social Trends, September 2010 (ABS cat. no. 4102.0). Canberra: ABS, pp. 2128.

Barbieri, P. (2009). Flexible employment and inequality in Europe. European Sociological Review, 25, 621-628.

Barbieri, P. and Cutuli, G. (2016). Employment protection legislation, labour market dualism, and inequality in Europe. European Sociological Review, 32, 501-516.

Barbieri, P. and Scherer, S. (2009). Labour market flexibilization and its consequences in Italy. European Sociological Review, 25, 677-692.

Baxter, J. (2013). Employment and the life course: birth cohort differences of young Australian women. In Evans, A. and Baxter, J. (Eds.), Negotiating the Life Course: Stability and Change in Life Pathways. New York: Springer, pp. 99-120.

Blossfeld, H.-P. et al. (Eds.) (2005). Globalization, Uncertainty and Youth in Society. London: Routledge.

Booth, A. L., Francesconi, M. and Frank, J. (2002). Temporary jobs: stepping stones or dead ends? The Economic Journal, 112, F189-F213.

Boyce, A. S. et al. (2007). Temporary worker, permanent loser? A model of the stigmatization of temporary workers. Journal of Management, 33, 5-29. 
Brzinsky-Fay, C. (2007). Lost in transition? Labour market sequences of school-leavers in Europe. European Sociological Review, 23, 409-422.

Brzinsky-Fay, C., Kohler, U. and Luniak, M. (2006). Sequence analysis with Stata. The Stata Journal, 6, 435-460.

Buddelmeyer, H. and Wooden, M. (2011). Transitions out of casual employment: the Australian experience. Industrial Relations, 50, 109-130.

Craig, L. and Mullan, K. (2009). “The policeman and the part-time sales assistant”: household labour supply, family time and subjective time pressure in Australia 1997-2006. Journal of Comparative Family Studies, 40, 547-561.

de Graaf-Zijl, M., van den Berg, G. J. and Heyma, A. (2011). Stepping stones for the unemployed: the effect of temporary jobs on the duration until (regular) work. Journal of Population Economics, 24, 107-139.

DiPrete, T. A. et al. (2006). Work and pay in flexible and regulated labor markets: a generalized perspective on institutional evolution and inequality trends in Europe and the US. Research in Social Stratification and Mobility, 24, 311-32.

Doeringer, P. B. and Piore, M. J. (1971). Internal Labour Markets and Manpower Analysis. Lexington, MA: Heath.

Esping-Andersen, G. (1999). Social Foundations of Postindustrial Economies. Oxford, New York: Oxford University Press.

Esteban-Pretel, J., Nakajima, R. and Tanaka, R. (2011). Are contingent jobs dead ends or stepping stones to regular jobs? Evidence from a structural estimation. Labour Economics, 18, 513-526.

Eurofound (2015). New Forms of Employment. Luxembourg: Publications Office of the European Union. 
Faccini, R. (2014). Reassessing labour market reforms: temporary contracts as a screening device. The Economic Journal, 124, 167-200.

Fuller, S. and Stecy-Hildebrandt, N. (2015). Career pathways for temporary workers: exploring heterogeneous mobility dynamics with sequence analysis. Social Science Research, 50, 76-99.

Gash, V. (2008). Bridge or trap? Temporary workers' transitions to unemployment and to the standard employment contract. European Sociological Review, 24, 651-668.

Gebel, M. and Giesecke, J. (2016). Does deregulation help? The impact of employment protection reforms on youths' unemployment and temporary employment risks in Europe. European Sociological Review, 32, 486-500.

Giesecke, J. (2009). Socio-economic risks of atypical employment relationships: evidence from the German labour market. European Sociological Review, 25, 629-646.

Giesecke, J. and Groß, M. (2003). Temporary employment: chance or risk? European Sociological Review, 19, 161-177.

Güell, M. and Petrongolo, B. (2007). How binding are legal limits? Transitions from temporary to permanent work in Spain. Labour Economics, 14, 153-184.

Hakim, C. (2006). Women, careers, and work-life preferences. British Journal of Guidance \& Counselling, 34, 279-294.

Kalleberg, A. L. (2009). Precarious work, insecure workers: employment relations in transition. American Sociological Review, 74, 1-22.

Kalleberg, A. L. et al. (1997). Nonstandard Work, Substandard Jobs: Flexible Work Arrangements in the U.S. Washington DC: Economic Policy Institute.

Kalleberg, A. L., Reskin, B. F. and Hudson, K. (2000). Bad jobs in America: standard and nonstandard employment relations and job quality in the United States. American Sociological Review, 65, 256-278. 
Kohli, M. (2007). The institutionalization of the life course: looking back to look ahead. Research in Human Development, 4, 253-271.

Korpi, T. and Levin, H. (2001). Precarious footing: temporary employment as a stepping stone out of unemployment in Sweden. Work, Employment \& Society, 15, 127-148.

Mayer, K. U. (2005). Life courses and life chances in a comparative perspective. In Svallfors, S. (Ed.). Analyzing Inequality: Life Chances and Social Mobility in Comparative Perspective. Stanford, CA: Stanford University Press, pp. 17-55

McGovern, P., Smeaton, D. and Hill, S. (2004). Bad jobs in Britain: nonstandard employment and job quality. Work and Occupations, 31, 225-249.

McGrath, D. M. and Keister, L. A. (2008). The effect of temporary employment on asset accumulation processes. Work and Occupations, 35, 196-222.

McVicar, D. and Anyadike-Danes, M. (2002). Predicting successful and unsuccessful transitions from school to work by using sequence methods. Journal of the Royal Statistical Society: Series A, 165, 317-334.

McVicar, D., Wooden, M., Leung, F. and Li, N. (2016). Work-related training and the probability of transitioning from non-standard to permanent employment. British Journal of Industrial Relations, 54, 623-646.

Mills, M. and Blossfeld, H.-P. (2013). The Second Demographic Transition meets globalization: a comprehensive theory to understand changes in family formation in an era of rising uncertainty. In Evans, A. and Baxter, J. (Eds.). Negotiating the Life Course: Stability and Change in Life Pathways. New York: Springer, pp. 9-28.

Mooi-Reci, I. and Dekker, R. (2015). Fixed-term contracts: short-term blessings or long-term scars? Empirical findings from the Netherlands 1989-2000. British Journal of Industrial Relations, 53, 112-135. 
Mooi-Reci, I. and Wooden, M. (2017). Casual employment and long-term wage outcomes. Human Relations, 70, 1064-1090.

Morris, M. D. S. and Vekker, A. (2001). An alternative look at temporary workers, their choices, and the growth in temporary employment. Journal of Labor Research, 22, 373 390.

Nienhüser, W. and Matiaske, W. (2006). Effects of the "principle of non-discrimination" on temporary agency work: compensation and working conditions of temporary agency workers in 15 European countries. Industrial Relations Journal, 37, 64-77.

Noelke, C. (2016). Employment protection legislation and the youth labour market. European Sociological Review, 32, 471-485.

OECD (2013). Protecting jobs, enhancing flexibility: a new look at employment protection legislation. In OECD Employment Outlook 2013. Paris: OECD Publishing, pp. 65-126.

OECD (2014). Non-regular employment, job security and the labour market divide. In $O E C D$ Employment Outlook 2014. Paris: OECD Publishing, pp. 141-209.

OECD (2017). Pensions at a Glance 2017: OECD and G20 Indicators. Paris: OECD Publishing.

Olsthoorn, M. (2016). Institution-driven inequalities in the risk of temporary employment: job or skill based? The relative deregulation of temporary employment and its relation to inequalities in the risk of temporary employment. European Sociological Review, 32, 517531.

Office for National Statistics [ONS] (2017). Contracts that do not guarantee a minimum number of hours: September 2017. Newport: Office for National Statistics.

Prosser, T. (2016). Dualization or liberalization? Investigating precarious work in eight European countries. Work, Employment \& Society, 30, 949-965. 
Rebitzer, J. B. and Taylor, L. J. (1991). A model of dual labour markets when product demand is uncertain. Quarterly Journal of Economics, 106, 1373-1383.

Stewart, A. et al. (2016). Creighton \& Stewart's Labour Law. Annandale, NSW: The Federation Press.

Summerfield, M. et al. (2015). HILDA User Manual-Release 14. Melbourne: University of Melbourne.

Watson, I. (2013). Bridges or traps? Casualisation and labour market transitions in Australia. Journal of Industrial Relations, 55, 6-37.

Watson, N. and Wooden, M. (2012). The HILDA Survey: a case study in the design and development of a successful household panel study. Longitudinal and Life Course Studies, 3, 369-381.

Wilkins, R. and Wooden, M. (2014). Two decades of change: the Australian labour market, 1993-2013. Australian Economic Review, 47, 417-431.

Yu, W. H. (2012). Better off jobless? Scarring effects of contingent employment in Japan. Social Forces, 90, 735-768. 
Table 1. Labour market state by sex and age (\% of working-age population), 2001-14

\begin{tabular}{|c|c|c|c|c|}
\hline \multirow{2}{*}{$\begin{array}{l}\text { Sex / Labour } \\
\text { market state }\end{array}$} & \multicolumn{4}{|c|}{ Age group (years) } \\
\hline & $15-24$ & $25-54$ & $55-64$ & $15-64$ \\
\hline \multicolumn{5}{|l|}{ Persons } \\
\hline Permanent full-time employee & 20.4 & 42.0 & 21.9 & 34.5 \\
\hline Permanent part-time employee & 5.8 & 8.4 & 6.8 & 7.6 \\
\hline Fixed term contract employee & 5.2 & 6.5 & 3.2 & 5.7 \\
\hline Casual employee & 31.0 & 10.0 & 7.0 & 14.0 \\
\hline Other employed & 2.1 & 13.0 & 14.6 & 10.9 \\
\hline Not employed & 35.5 & 20.1 & 46.5 & 27.3 \\
\hline Total & 100.0 & 100.0 & 100.0 & 100.0 \\
\hline \multicolumn{5}{|l|}{ Men } \\
\hline Permanent full-time employee & 23.5 & 54.4 & 28.0 & 43.8 \\
\hline Permanent part-time employee & 4.3 & 2.1 & 2.8 & 2.7 \\
\hline Fixed term contract employee & 5.8 & 6.5 & 3.5 & 5.9 \\
\hline Casual employee & 28.2 & 7.7 & 6.8 & 12.0 \\
\hline Other employed & 2.8 & 17.4 & 20.3 & 14.7 \\
\hline Not employed & 35.4 & 11.9 & 38.6 & 20.9 \\
\hline Subtotal & 100.0 & 100.0 & 100.0 & 100.0 \\
\hline \multicolumn{5}{|l|}{ Women } \\
\hline Permanent full-time employee & 17.2 & 29.8 & 15.8 & 25.2 \\
\hline Permanent part-time employee & 7.3 & 14.6 & 10.8 & 12.5 \\
\hline Fixed term contract employee & 4.6 & 6.5 & 2.9 & 5.6 \\
\hline Casual employee & 33.9 & 12.2 & 7.3 & 16.0 \\
\hline Other employed & 1.3 & 8.7 & 8.9 & 7.2 \\
\hline Not employed & 35.7 & 28.2 & 54.3 & 33.6 \\
\hline Subtotal & 100.0 & 100.0 & 100.0 & 100.0 \\
\hline
\end{tabular}

Note: Cross-sectional population-weighted estimates for the pooled HILDA Survey sample, waves 1-14. 
Table 2. Variable definitions and sample means: analysis sample

\begin{tabular}{|c|c|c|}
\hline Variable & Definition & Mean \\
\hline Full-time permanent & Employed full-time on a permanent contract & 0.32 \\
\hline Part-time permanent & Employed part-time on a permanent contract & 0.07 \\
\hline Fixed-term employment & Employed on a fixed-term contract & 0.05 \\
\hline Casual employment & Employed on a casual basis & 0.16 \\
\hline Other employed & Employed on some other arrangement (mostly self-employed) & 0.12 \\
\hline Not employed & Not employed & 0.28 \\
\hline Male & Gender is male & 0.47 \\
\hline Non-indigenous Australian & Born in Australia and not of indigenous origin & 0.78 \\
\hline Indigenous Australian & Born in Australia and of indigenous origin & 0.02 \\
\hline Born overseas / ESC & Born overseas in one of the main English-speaking countries & 0.09 \\
\hline Born overseas / NESC & Born overseas in a non-English-speaking country & 0.11 \\
\hline Less than Year 12 & Did not complete high school (i.e. Year 12) & 0.24 \\
\hline Year 12 & Completed high school (i.e., Year 12) & 0.13 \\
\hline Certificate / Diploma & Attained certificate level III or IV or a diploma & 0.35 \\
\hline Tertiary qualification & Completed tertiary education & 0.28 \\
\hline Father manager & Father's occupation was Manager when respondent aged $14^{\mathrm{a}}$ & 0.23 \\
\hline Father professional & Father's occupation was Professional when respondent aged $14^{\mathrm{a}}$ & 0.16 \\
\hline Father trades & $\begin{array}{l}\text { Father's occupation was Technician or Trades Worker when } \\
\text { respondent aged } 14^{\mathrm{a}}\end{array}$ & 0.23 \\
\hline Father personal service & $\begin{array}{l}\text { Father's occupation was Community or Personal Services Worker } \\
\text { when respondent aged } 14^{\mathrm{a}}\end{array}$ & 0.04 \\
\hline Father clerical \& admin & $\begin{array}{l}\text { Father's occupation was Clerical or Administrative Worker when } \\
\text { respondent aged } 14^{\mathrm{a}}\end{array}$ & 0.06 \\
\hline Father sales & Father's occupation was Sales Worker when respondent aged $14^{\mathrm{a}}$ & 0.05 \\
\hline Father machine operator & $\begin{array}{l}\text { Father's occupation was Machinery Operator or Driver when } \\
\text { respondent aged } 14^{\mathrm{a}}\end{array}$ & 0.10 \\
\hline Father labourer & Father's occupation was Labourer when respondent aged $14^{\mathrm{a}}$ & 0.11 \\
\hline Father occupation missing & Father's occupation missing ${ }^{\mathrm{a}}$ & 0.03 \\
\hline $\begin{array}{l}\text { Father did not complete } \\
\text { high school }\end{array}$ & Father did not complete Year $11^{\mathrm{a}}$ & 0.33 \\
\hline Father high school & Father completed Year 11 or $12^{\mathrm{a}}$ & 0.07 \\
\hline Father post-school educ. & Father completed post-secondary qualification ${ }^{\mathrm{a}}$ & 0.52 \\
\hline Father education missing & Father's education missing ${ }^{a}$ & 0.07 \\
\hline Openness to experience & Mean score on 6-item trait descriptive adjective index $(1-7 \text { scale })^{\mathrm{b}}$ & 4.28 \\
\hline Conscientiousness & Mean score on 6-item trait descriptive adjective index (1-7 scale $)^{b}$ & 5.03 \\
\hline Extroversion & Mean score on 6-item trait descriptive adjective index $(1-7 \text { scale })^{\mathrm{b}}$ & 4.45 \\
\hline Agreeableness & Mean score on 4-item trait descriptive adjective index $(1-7 \text { scale })^{b}$ & 5.37 \\
\hline Emotional stability & Mean score on 6-item trait descriptive adjective index $(1-7 \text { scale })^{\mathrm{b}}$ & 5.10 \\
\hline Big-5 Missing & At least one of the Big-5 personality traits is missing & 0.03 \\
\hline $\begin{array}{l}\text { Cognitive ability } \\
\text { (backward digits span) }\end{array}$ & Ability to recite sequence of digits backwards $(0-7 \text { scale })^{\mathrm{b}}$ & 3.98 \\
\hline BDS Missing & Backward digits span score missing & 0.08 \\
\hline $\begin{array}{l}\text { Cognitive ability (symbol } \\
\text { digit modalities) }\end{array}$ & $\begin{array}{l}\text { Ability to match symbols to numbers (correct number of } \\
\text { responses within } 90 \text { seconds) }\end{array}$ & 50.14 \\
\hline SDS missing & Symbol digit modalities score missing & 0.17 \\
\hline Attitude to financial risk & Attitude to financial risk $(1-4 \text { scale })^{\mathrm{b}}$ & 3.35 \\
\hline Financial attitude missing & Attitude to financial risk missing & 0.00 \\
\hline Age $<19$ & Aged $<19$ on $30^{\text {th }}$ June preceding interview & 0.14 \\
\hline Age 19-24 & Aged $19-24$ on $30^{\text {th }}$ June preceding interview & 0.10 \\
\hline Age $25-49$ & Aged $25-49$ on $30^{\text {th }}$ June preceding interview & 0.59 \\
\hline Age $50-59$ & Aged $50-59$ on $30^{\text {th }}$ June preceding interview & 0.17 \\
\hline Partnered & Married or de facto & 0.62 \\
\hline $\begin{array}{l}\text { Long-term health } \\
\text { condition }\end{array}$ & Has a moderate or severe work-limiting health condition & 0.12 \\
\hline Pre-school child & Youngest dependent child aged $0-5$ years & 0.19 \\
\hline School-age child & Youngest dependent child aged 6-18 years & 0.19 \\
\hline
\end{tabular}


No dependent child aged

18 or less

Labour force experience

Local unemployment rate
Has no dependent children aged 18 years or less

Years spent in employment since leaving full-time education Unemployment rate at the SA4 level (at interview month)

Notes: The sample is all those observed for at least ten waves between wave 1 and wave 14 , initially aged 1559. Sample means relate to each respondent's first measurement of the respective characteristic, except in the case of the respondent's educational level, where the last available information is used.

a If father was missing or did not give a valid response, then information given about the mother was used instead.

b For further details about the construction of these variables, see Summerfield et al. (2015). 
Table 3. Average year-to-year transitions: unweighted analysis sample (\%)

\begin{tabular}{|c|c|c|c|c|c|c|c|c|}
\hline \multirow[b]{2}{*}{$\begin{array}{l}\text { Labour market } \\
\text { state at } \mathrm{t}\end{array}$} & \multicolumn{6}{|c|}{ Labour market state at $\mathrm{t}+1$} & \multirow[b]{2}{*}{$\begin{array}{l}\text { Non- } \\
\text { response }\end{array}$} & \multirow[b]{2}{*}{ Total } \\
\hline & $\begin{array}{l}\text { Perman’t } \\
\text { FT }\end{array}$ & $\begin{array}{l}\text { Perman’t } \\
\text { PT }\end{array}$ & $\begin{array}{l}\text { Fixed } \\
\text { term }\end{array}$ & Casual & $\begin{array}{c}\text { Other } \\
\text { employed }\end{array}$ & $\begin{array}{c}\text { Not } \\
\text { employed }\end{array}$ & & \\
\hline $\begin{array}{l}\text { Permanent full- } \\
\text { time }\end{array}$ & 27.82 & 1.06 & 1.72 & 0.99 & 0.75 & 1.29 & 0.83 & 34.46 \\
\hline $\begin{array}{l}\text { Permanent } \\
\text { part-time }\end{array}$ & 1.09 & 4.95 & 0.42 & 0.66 & 0.20 & 0.66 & 0.18 & 8.15 \\
\hline Fixed term & 2.00 & 0.46 & 2.17 & 0.36 & 0.19 & 0.36 & 0.16 & 5.69 \\
\hline Casual & 1.48 & 0.87 & 0.63 & 6.23 & 0.46 & 1.66 & 0.29 & 11.62 \\
\hline $\begin{array}{l}\text { Other } \\
\text { employed }\end{array}$ & 0.57 & 0.19 & 0.21 & 0.47 & 9.75 & 0.81 & 0.30 & 12.31 \\
\hline Not employed & 0.82 & 0.66 & 0.41 & 2.10 & 0.70 & 19.20 & 0.59 & 24.48 \\
\hline Non-response & 0.68 & 0.13 & 0.13 & 0.26 & 0.24 & 0.54 & 1.31 & 3.29 \\
\hline
\end{tabular}


Table 4. Typology of labour market pathways (7-cluster solution)

\begin{tabular}{|c|c|c|c|c|c|c|c|c|c|}
\hline & \multirow[b]{2}{*}{$\begin{array}{l}\text { Cluster } \\
\text { size }\end{array}$} & \multirow[b]{2}{*}{$\begin{array}{l}\text { Modal sequence } \\
\text { type }\end{array}$} & \multicolumn{7}{|c|}{$\begin{array}{l}\text { Average } \% \text { of waves ( } \% \text { of individuals experiencing) } \\
\text { in state }\end{array}$} \\
\hline & & & FTP & PTP & FXT & CAS & $\mathrm{OE}$ & $\mathrm{NE}$ & NR \\
\hline $\begin{array}{l}\text { (1) Persistent } \\
\text { full-time } \\
\text { permanent }\end{array}$ & 2315 & All FTP & $\begin{array}{c}80.6 \\
(100)\end{array}$ & $\begin{array}{c}1.9 \\
(16.5)\end{array}$ & $\begin{array}{c}6.0 \\
(41.2)\end{array}$ & $\begin{array}{c}2.7 \\
(24.4)\end{array}$ & $\begin{array}{c}2.3 \\
(15.0)\end{array}$ & $\begin{array}{c}2.6 \\
(23.5)\end{array}$ & $\begin{array}{c}3.8 \\
(26.6)\end{array}$ \\
\hline $\begin{array}{l}\text { (2) Exits from } \\
\text { full-time } \\
\text { permanent } \\
\text { and churn }\end{array}$ & 1132 & $\mathrm{FTP} \rightarrow \mathrm{NE}$ & $\begin{array}{c}41.0 \\
(96.6)\end{array}$ & $\begin{array}{c}14.1 \\
(52.0)\end{array}$ & $\begin{array}{c}13.2 \\
(50.4)\end{array}$ & $\begin{array}{c}9.6 \\
(49.5)\end{array}$ & $\begin{array}{c}2.1 \\
(18.5)\end{array}$ & $\begin{array}{c}17.2 \\
(67.5)\end{array}$ & $\begin{array}{c}2.7 \\
(21.5)\end{array}$ \\
\hline $\begin{array}{l}\text { (3) Casual to } \\
\text { full-time } \\
\text { permanent }\end{array}$ & 672 & $\mathrm{NE} \rightarrow \mathrm{CAS} \rightarrow \mathrm{FTP}$ & $\begin{array}{l}45.3 \\
(100)\end{array}$ & $\begin{array}{c}5.0 \\
(37.9)\end{array}$ & $\begin{array}{c}8.2 \\
(52.7)\end{array}$ & $\begin{array}{c}19.7 \\
(88.8)\end{array}$ & $\begin{array}{c}1.5 \\
(14.0)\end{array}$ & $\begin{array}{c}15.7 \\
(74.4)\end{array}$ & $\begin{array}{c}4.6 \\
(32.7)\end{array}$ \\
\hline $\begin{array}{l}\text { (4) Persistent } \\
\text { casual and } \\
\text { casual churn }\end{array}$ & 651 & All CAS & $\begin{array}{c}11.4 \\
(61.1)\end{array}$ & $\begin{array}{c}8.0 \\
(46.4)\end{array}$ & $\begin{array}{c}5.7 \\
(39.8)\end{array}$ & $\begin{array}{c}55.1 \\
(99.8)\end{array}$ & $\begin{array}{c}2.3 \\
(18.3)\end{array}$ & $\begin{array}{c}13.5 \\
(71.9)\end{array}$ & $\begin{array}{c}4.1 \\
(27.6)\end{array}$ \\
\hline $\begin{array}{l}\text { (5) Part-time } \\
\text { permanent }\end{array}$ & 704 & $\mathrm{PTP} \rightarrow \mathrm{NE}$ & $\begin{array}{c}8.4 \\
(49.6)\end{array}$ & $\begin{array}{c}50.4 \\
(99.9)\end{array}$ & $\begin{array}{c}6.2 \\
(41.2)\end{array}$ & $\begin{array}{c}9.9 \\
(56.7)\end{array}$ & $\begin{array}{c}2.7 \\
(17.3)\end{array}$ & $\begin{array}{c}19.7 \\
(71.9)\end{array}$ & $\begin{array}{c}2.7 \\
(23.9)\end{array}$ \\
\hline $\begin{array}{l}\text { (6) Other } \\
\text { employed }\end{array}$ & 1325 & All OS & $\begin{array}{c}10.9 \\
(45.2)\end{array}$ & $\begin{array}{c}1.9 \\
(14.8)\end{array}$ & $\begin{array}{c}2.6 \\
(19.7)\end{array}$ & $\begin{array}{c}5.6 \\
(33.1)\end{array}$ & $\begin{array}{l}65.8 \\
(100)\end{array}$ & $\begin{array}{c}9.2 \\
(43.9)\end{array}$ & $\begin{array}{c}3.9 \\
(28.3)\end{array}$ \\
\hline $\begin{array}{l}\text { (7) Not } \\
\text { employed }\end{array}$ & 1895 & All NE & $\begin{array}{c}3.0 \\
(23.3)\end{array}$ & $\begin{array}{c}2.3 \\
(19.1)\end{array}$ & $\begin{array}{c}1.8 \\
(14.2)\end{array}$ & $\begin{array}{c}10.2 \\
(47.9)\end{array}$ & $\begin{array}{c}3.2 \\
(20.0)\end{array}$ & $\begin{array}{c}76.3 \\
(100)\end{array}$ & $\begin{array}{c}3.2 \\
(23.6)\end{array}$ \\
\hline Overall sample & 8694 & All FTP & $\begin{array}{c}34.2 \\
(67.5)\end{array}$ & $\begin{array}{c}8.2 \\
(32.1)\end{array}$ & $\begin{array}{c}5.7 \\
(34.0)\end{array}$ & $\begin{array}{c}11.4 \\
(47.3)\end{array}$ & $\begin{array}{c}12.2 \\
(29.8)\end{array}$ & $\begin{array}{c}24.7 \\
(60.5)\end{array}$ & $\begin{array}{c}3.6 \\
(25.9)\end{array}$ \\
\hline
\end{tabular}

Key: FTP=Full-time permanent; PTP=Part-time permanent; FXT=Fixed-term; CAS=Casual; OE=Other employment; $\mathrm{NE}=$ Not employed; NR=Non-response. 
Table 5. Factors predicting cluster: MNL estimates (coefficients, standard errors, and relative risk ratios)

\begin{tabular}{|c|c|c|c|c|c|c|}
\hline \multirow[t]{2}{*}{ Variable } & \multicolumn{6}{|c|}{ Cluster } \\
\hline & $\begin{array}{l}\text { Exits from } \\
\text { FT perm }\end{array}$ & $\begin{array}{l}\text { Casual } \\
\text { bridge }\end{array}$ & $\begin{array}{c}\text { Casual } \\
\text { trap }\end{array}$ & PT perm & $\begin{array}{l}\text { Other } \\
\text { empl'd }\end{array}$ & $\begin{array}{c}\text { Not } \\
\text { empl'd }\end{array}$ \\
\hline \multicolumn{7}{|l|}{ Gender (ref. $=$ women $)$} \\
\hline Male & $\begin{array}{l}-1.574 * * * \\
(0.088) \\
{[0.207]}\end{array}$ & $\begin{array}{l}-0.919 * * * \\
(0.109) \\
{[0.399]}\end{array}$ & $\begin{array}{l}-1.727 * * * \\
(0.112) \\
{[0.178]}\end{array}$ & $\begin{array}{l}-3.316^{* * * *} \\
(0.149) \\
{[0.036]}\end{array}$ & $\begin{array}{l}-0.559 * * * \\
(0.085) \\
{[0.572]}\end{array}$ & $\begin{array}{l}-2.041 \text { *** } \\
(0.089) \\
{[0.130]}\end{array}$ \\
\hline \multicolumn{7}{|c|}{ Origin (ref. = non-indigenous Australian) } \\
\hline Indigenous Australian & $\begin{array}{l}-0.227 \\
(0.348) \\
{[0.797]}\end{array}$ & $\begin{array}{l}-0.006 \\
(0.334) \\
{[0.994]}\end{array}$ & $\begin{array}{l}-0.125 \\
(0.356) \\
{[0.882]}\end{array}$ & $\begin{array}{c}0.239 \\
(0.349) \\
{[1.270]}\end{array}$ & $\begin{array}{l}-0.374 \\
(0.379) \\
{[0.688]}\end{array}$ & $\begin{array}{l}0.883^{* * * *} \\
(0.254) \\
{[2.419]}\end{array}$ \\
\hline Born overseas / ESC & $\begin{array}{c}0.118 \\
(0.128) \\
{[1.125]}\end{array}$ & $\begin{array}{c}0.006 \\
(0.209) \\
{[1.006]}\end{array}$ & $\begin{array}{l}-0.208 \\
(0.204) \\
{[0.813]}\end{array}$ & $\begin{array}{c}0.093 \\
(0.162) \\
{[1.098]}\end{array}$ & $\begin{array}{c}0.162 \\
(0.118) \\
{[1.176]}\end{array}$ & $\begin{array}{c}0.156 \\
(0.134) \\
{[1.169]}\end{array}$ \\
\hline Born overseas / NESC & $\begin{array}{l}-0.043 \\
(0.133) \\
{[0.958]}\end{array}$ & $\begin{array}{c}0.385^{* *} \\
(0.161) \\
{[1.470]}\end{array}$ & $\begin{array}{l}-0.015 \\
(0.177) \\
{[0.985]}\end{array}$ & $\begin{array}{l}-0.134 \\
(0.166) \\
{[0.875]}\end{array}$ & $\begin{array}{c}0.218^{*} \\
(0.121) \\
{[1.244]}\end{array}$ & $\begin{array}{l}0.587 * * * \\
(0.121) \\
{[1.799]}\end{array}$ \\
\hline \multicolumn{7}{|c|}{ Educational level (ref. = below Year 12) } \\
\hline Year 12 & $\begin{array}{l}-0.064 \\
(0.151) \\
{[0.938]}\end{array}$ & $\begin{array}{l}-0.171 \\
(0.176) \\
{[0.843]}\end{array}$ & $\begin{array}{l}-0.591 * * * \\
(0.173) \\
{[0.554]}\end{array}$ & $\begin{array}{l}-0.269 \\
(0.174) \\
{[0.764]}\end{array}$ & $\begin{array}{l}-0.360 * * \\
(0.140) \\
{[0.698]}\end{array}$ & $\begin{array}{l}-0.653^{* * *} \\
(0.133) \\
{[0.520]}\end{array}$ \\
\hline Certificate / Diploma & $\begin{array}{l}-0.166 \\
(0.115) \\
{[0.847]}\end{array}$ & $\begin{array}{l}-0.279 * \\
(0.149) \\
{[0.757]}\end{array}$ & $\begin{array}{l}-0.640 * * * \\
(0.136) \\
{[0.527]}\end{array}$ & $\begin{array}{l}-0.240 * \\
(0.131) \\
{[0.787]}\end{array}$ & $\begin{array}{l}-0.378^{* * *} \\
(0.102) \\
{[0.685]}\end{array}$ & $\begin{array}{l}-0.925^{* * *} \\
(0.102) \\
{[0.397]}\end{array}$ \\
\hline Tertiary qualification & $\begin{array}{c}0.065 \\
(0.126) \\
{[1.068]}\end{array}$ & $\begin{array}{l}-0.308^{*} \\
(0.165) \\
{[0.735]}\end{array}$ & $\begin{array}{l}-0.715 * * * \\
(0.154) \\
{[0.489]}\end{array}$ & $\begin{array}{l}-0.365^{* *} \\
(0.148) \\
{[0.694]}\end{array}$ & $\begin{array}{l}-0.835^{* * * *} \\
(0.119) \\
{[0.434]}\end{array}$ & $\begin{array}{l}-1.416^{* * *} \\
(0.123) \\
{[0.243]}\end{array}$ \\
\hline \multicolumn{7}{|c|}{ Father's educational level (ref. = did not complete high-school) } \\
\hline Father high school & $\begin{array}{c}0.007 \\
(0.158) \\
{[1.007]}\end{array}$ & $\begin{array}{c}0.125 \\
(0.199) \\
{[1.133]}\end{array}$ & $\begin{array}{l}-0.141 \\
(0.209) \\
{[0.868]}\end{array}$ & $\begin{array}{l}-0.049 \\
(0.196) \\
{[0.952]}\end{array}$ & $\begin{array}{l}-0.008 \\
(0.149) \\
{[0.992]}\end{array}$ & $\begin{array}{l}-0.094 \\
(0.162) \\
{[0.910]}\end{array}$ \\
\hline Father post-school educ. & $\begin{array}{l}-0.078 \\
(0.095) \\
{[0.925]}\end{array}$ & $\begin{array}{c}0.198 \\
(0.126) \\
{[1.219]}\end{array}$ & $\begin{array}{c}0.059 \\
(0.122) \\
{[1.061]}\end{array}$ & $\begin{array}{l}-0.160 \\
(0.115) \\
{[0.852]}\end{array}$ & $\begin{array}{l}-0.167 * \\
(0.088) \\
{[0.846]}\end{array}$ & $\begin{array}{l}-0.061 \\
(0.093) \\
{[0.941]}\end{array}$ \\
\hline Openness to experience & $\begin{array}{c}0.076^{*} \\
(0.042) \\
{[1.079]}\end{array}$ & $\begin{array}{l}0.160^{* * *} \\
(0.054) \\
{[1.173]}\end{array}$ & $\begin{array}{l}0.112 * * \\
(0.053) \\
{[1.119]}\end{array}$ & $\begin{array}{l}-0.029 \\
(0.051) \\
{[0.971]}\end{array}$ & $\begin{array}{l}0.280 * * * \\
(0.041) \\
{[1.323]}\end{array}$ & $\begin{array}{l}0.277 * * * \\
(0.041) \\
{[1.319]}\end{array}$ \\
\hline Conscientiousness & $\begin{array}{l}-0.096 * * \\
(0.041) \\
{[0.908]}\end{array}$ & $\begin{array}{l}-0.170 * * * \\
(0.052) \\
{[0.844]}\end{array}$ & $\begin{array}{l}-0.224 * * * \\
(0.051) \\
{[0.800]}\end{array}$ & $\begin{array}{l}-0.112 * * \\
(0.050) \\
{[0.894]}\end{array}$ & $\begin{array}{l}-0.176 * * * \\
(0.040) \\
{[0.838]}\end{array}$ & $\begin{array}{l}-0.212 * * * \\
(0.041) \\
{[0.809]}\end{array}$ \\
\hline Extroversion & $\begin{array}{c}0.003 \\
(0.037) \\
{[1.003]}\end{array}$ & $\begin{array}{c}0.039 \\
(0.048) \\
{[1.040]}\end{array}$ & $\begin{array}{c}0.005 \\
(0.047) \\
{[1.005]}\end{array}$ & $\begin{array}{l}-0.084 * \\
(0.045) \\
{[0.920]}\end{array}$ & $\begin{array}{l}0.076^{* *} \\
(0.036) \\
{[1.079]}\end{array}$ & $\begin{array}{l}-0.115^{* * *} \\
(0.037) \\
{[0.891]}\end{array}$ \\
\hline Agreeableness & $\begin{array}{l}-0.043 \\
(0.050) \\
{[0.958]}\end{array}$ & $\begin{array}{l}-0.001 \\
(0.061) \\
{[0.999]}\end{array}$ & $\begin{array}{c}0.071 \\
(0.062) \\
{[1.074]}\end{array}$ & $\begin{array}{c}0.016 \\
(0.062) \\
{[1.016]}\end{array}$ & $\begin{array}{l}-0.070 \\
(0.047) \\
{[0.932]}\end{array}$ & $\begin{array}{l}-0.119 * * \\
(0.048) \\
{[0.888]}\end{array}$ \\
\hline Emotional stability & 0.004 & -0.003 & 0.028 & 0.064 & $0.160 * * *$ & 0.064 \\
\hline
\end{tabular}




\begin{tabular}{|c|c|c|c|c|c|c|}
\hline & $\begin{array}{l}(0.040) \\
{[1.004]}\end{array}$ & $\begin{array}{l}(0.050) \\
{[0.997]}\end{array}$ & $\begin{array}{l}(0.050) \\
{[1.028]}\end{array}$ & $\begin{array}{l}(0.050) \\
{[1.066]}\end{array}$ & $\begin{array}{l}(0.039) \\
{[1.173]}\end{array}$ & $\begin{array}{l}(0.039) \\
{[1.066]}\end{array}$ \\
\hline $\begin{array}{l}\text { Cognitive ability (backward } \\
\text { digits span) }\end{array}$ & $\begin{array}{l}-0.031 \\
(0.029) \\
{[0.969]}\end{array}$ & $\begin{array}{l}-0.067 * \\
(0.037) \\
{[0.935]}\end{array}$ & $\begin{array}{l}-0.008 \\
(0.037) \\
{[0.992]}\end{array}$ & $\begin{array}{l}-0.039 \\
(0.036) \\
{[0.962]}\end{array}$ & $\begin{array}{l}-0.011 \\
(0.028) \\
{[0.989]}\end{array}$ & $\begin{array}{l}-0.082 * * * \\
(0.029) \\
{[0.921]}\end{array}$ \\
\hline $\begin{array}{l}\text { Cognitive ability (symbol } \\
\text { digit modalities) }\end{array}$ & $\begin{array}{l}-0.016^{* * *} \\
(0.004) \\
{[0.984]}\end{array}$ & $\begin{array}{l}-0.010^{*} \\
(0.006) \\
{[0.990]}\end{array}$ & $\begin{array}{l}-0.020 * * * \\
(0.005) \\
{[0.980]}\end{array}$ & $\begin{array}{l}-0.017 * * * \\
(0.005) \\
{[0.983]}\end{array}$ & $\begin{array}{l}-0.014 * * * \\
(0.004) \\
{[0.986]}\end{array}$ & $\begin{array}{l}-0.043 * * * \\
(0.004) \\
{[0.957]}\end{array}$ \\
\hline Attitude to financial risk & $\begin{array}{c}0.020 \\
(0.056) \\
{[1.021]}\end{array}$ & $\begin{array}{c}0.065 \\
(0.068) \\
{[1.067]}\end{array}$ & $\begin{array}{c}0.087 \\
(0.071) \\
{[1.091]}\end{array}$ & $\begin{array}{c}0.043 \\
(0.072) \\
{[1.044]}\end{array}$ & $\begin{array}{l}-0.424 * * * \\
(0.049) \\
{[0.655]}\end{array}$ & $\begin{array}{l}0.132 * * \\
(0.056) \\
{[1.142]}\end{array}$ \\
\hline \multicolumn{7}{|l|}{ Age $($ ref.$=25-49$ years $)$} \\
\hline$<19$ years & $\begin{array}{l}0.521 * * * \\
(0.191) \\
{[1.684]}\end{array}$ & $\begin{array}{c}2.333 * * * \\
(0.211) \\
{[10.311]}\end{array}$ & $\begin{array}{c}2.757 * * * \\
(0.215) \\
{[15.760]}\end{array}$ & $\begin{array}{l}1.453 * * * \\
(0.224) \\
{[4.275]}\end{array}$ & $\begin{array}{c}0.018 \\
(0.212) \\
{[1.018]}\end{array}$ & $\begin{array}{l}1.187 * * * \\
(0.168) \\
{[3.276]}\end{array}$ \\
\hline 19-24 years & $\begin{array}{l}0.340 * * \\
(0.143) \\
{[1.405]}\end{array}$ & $\begin{array}{l}0.481 * * \\
(0.190) \\
{[1.618]}\end{array}$ & $\begin{array}{c}0.361 * \\
(0.206) \\
{[1.435]}\end{array}$ & $\begin{array}{l}-0.162 \\
(0.198) \\
{[0.851]}\end{array}$ & $\begin{array}{l}-0.596^{* * * *} \\
(0.170) \\
{[0.551]}\end{array}$ & $\begin{array}{l}-0.467 * * * \\
(0.151) \\
{[0.627]}\end{array}$ \\
\hline $50-59$ years & $\begin{array}{l}1.402 * * * \\
(0.158) \\
{[4.063]}\end{array}$ & $\begin{array}{l}0.933 * * * \\
(0.345) \\
{[2.542]}\end{array}$ & $\begin{array}{l}1.360 * * * \\
(0.237) \\
{[3.895]}\end{array}$ & $\begin{array}{l}1.876^{* * *} \\
(0.191) \\
{[6.527]}\end{array}$ & $\begin{array}{l}1.198 * * * \\
(0.150) \\
{[3.314]}\end{array}$ & $\begin{array}{l}3.315 * * * \\
(0.158) \\
{[27.523]}\end{array}$ \\
\hline Partnered & $\begin{array}{l}-0.000 \\
(0.096) \\
{[1.000]}\end{array}$ & $\begin{array}{l}-0.598 * * * \\
(0.143) \\
{[0.550]}\end{array}$ & $\begin{array}{l}-0.421 * * * \\
(0.135) \\
{[0.656]}\end{array}$ & $\begin{array}{c}0.208 * \\
(0.124) \\
{[1.231]}\end{array}$ & $\begin{array}{l}0.260 * * * \\
(0.099) \\
{[1.297]}\end{array}$ & $\begin{array}{c}0.030 \\
(0.098) \\
{[1.030]}\end{array}$ \\
\hline Long-term health condition & $\begin{array}{l}0.450 * * * \\
(0.158) \\
{[1.568]}\end{array}$ & $\begin{array}{l}0.818^{* * * *} \\
(0.194) \\
{[2.265]}\end{array}$ & $\begin{array}{l}1.021 * * * \\
(0.178) \\
{[2.775]}\end{array}$ & $\begin{array}{l}0.959 * * * \\
(0.176) \\
{[2.610]}\end{array}$ & $\begin{array}{l}0.587 * * * \\
(0.144) \\
{[1.799]}\end{array}$ & $\begin{array}{l}1.966 * * * \\
(0.129) \\
{[7.141]}\end{array}$ \\
\hline \multicolumn{7}{|c|}{ Youngest child (ref. $=$ no child below 18 years in income unit) } \\
\hline Pre-school child & $\begin{array}{l}-0.470 * * * \\
(0.122) \\
{[0.625]}\end{array}$ & $\begin{array}{l}0.799 * * * \\
(0.169) \\
{[2.223]}\end{array}$ & $\begin{array}{l}0.704 * * * \\
(0.161) \\
{[2.021]}\end{array}$ & $\begin{array}{l}0.721 * * * \\
(0.135) \\
{[2.057]}\end{array}$ & $\begin{array}{l}0.299 * * * \\
(0.103) \\
{[1.348]}\end{array}$ & $\begin{array}{l}0.519 * * * \\
(0.112) \\
{[1.681]}\end{array}$ \\
\hline School-age child & $\begin{array}{l}-0.230 * * \\
(0.108) \\
{[0.795]}\end{array}$ & $\begin{array}{l}0.723 * * * \\
(0.181) \\
{[2.060]}\end{array}$ & $\begin{array}{l}0.533 * * * \\
(0.158) \\
{[1.703]}\end{array}$ & $\begin{array}{l}0.433 * * * \\
(0.132) \\
{[1.541]}\end{array}$ & $\begin{array}{c}0.043 \\
(0.101) \\
{[1.044]}\end{array}$ & $\begin{array}{l}-0.111 \\
(0.114) \\
{[0.895]}\end{array}$ \\
\hline Labour force experience & $\begin{array}{c}0.003 \\
(0.006) \\
{[1.003]}\end{array}$ & $\begin{array}{l}-0.053 * * * \\
(0.010) \\
{[0.949]}\end{array}$ & $\begin{array}{l}-0.013 \\
(0.009) \\
{[0.987]}\end{array}$ & $\begin{array}{l}-0.015 * * \\
(0.007) \\
{[0.985]}\end{array}$ & $\begin{array}{c}0.004 \\
(0.006) \\
{[1.004]}\end{array}$ & $\begin{array}{l}-0.069 * * * \\
(0.006) \\
{[0.933]}\end{array}$ \\
\hline Local unemployment rate & $\begin{array}{c}0.017 \\
(0.017) \\
{[1.017]}\end{array}$ & $\begin{array}{l}0.067 * * * \\
(0.021) \\
{[1.069]}\end{array}$ & $\begin{array}{l}0.056^{* * * *} \\
(0.021) \\
{[1.058]}\end{array}$ & $\begin{array}{c}0.033 * \\
(0.020) \\
{[1.034]}\end{array}$ & $\begin{array}{l}0.037 * * \\
(0.016) \\
{[1.037]}\end{array}$ & $\begin{array}{l}0.058 * * * \\
(0.016) \\
{[1.060]}\end{array}$ \\
\hline Constant & $1.143 * *$ & -0.665 & -0.063 & $1.030 *$ & $0.839 *$ & $3.704 * * *$ \\
\hline
\end{tabular}

Notes:

$\mathrm{N}=8691$.

The base category is cluster 1 (persistent full-time permanent).

Figures in curved parentheses are robust standard errors; figures in square parentheses are relative risk ratios.

$*, * *$ and $* * *$ denote significance at the $10 \%, 5 \%$ and $1 \%$ levels, respectively.

Also included, but not reported, are 8 dummies for father's occupation at age 14. To preserve sample size, missing values for the personality, cognitive ability, and attitude to financial risk variables are set to their respective sample mean values and dummy variables identifying cases with missing observations on each of these variables included in the estimation. Additionally, the model includes a dummy variable for missing information on father's educational level. 


\section{Contingent Employment and Labour Market Pathways:}

\section{Bridge or Trap?}

Duncan McVicar, Mark Wooden, Inga Lass, and Yin-King Fok

\section{Supplementary Appendix: Tables and Figures}

Table S1. Sample means for analysis sample vs. all respondents aged 15-72

\begin{tabular}{|c|c|c|c|c|}
\hline \multirow[b]{2}{*}{ Variable } & \multicolumn{2}{|c|}{ Analysis sample } & \multicolumn{2}{|c|}{$\begin{array}{l}\text { Full } 14 \text { wave sample, } \\
15-72 \text { years }\end{array}$} \\
\hline & $\begin{array}{c}\text { First valid } \\
\text { value (except } \\
\text { education - last } \\
\text { valid value) }\end{array}$ & $\begin{array}{l}\text { Pooled } \\
\text { observations, } \\
\text { time-varying }\end{array}$ & $\begin{array}{c}\text { First valid } \\
\text { value (except } \\
\text { education - last } \\
\text { valid value) }\end{array}$ & $\begin{array}{c}\text { Pooled } \\
\text { observations, } \\
\text { time-varying }\end{array}$ \\
\hline Full-time permanent & 0.32 & 0.35 & 0.27 & 0.31 \\
\hline Part-time permanent & 0.07 & 0.08 & 0.05 & 0.07 \\
\hline Fixed-term employment & 0.05 & 0.06 & 0.05 & 0.05 \\
\hline Casual employment & 0.16 & 0.12 & 0.16 & 0.13 \\
\hline Other employed & 0.12 & 0.12 & 0.10 & 0.11 \\
\hline Not employed & 0.28 & 0.25 & 0.37 & 0.31 \\
\hline Male & 0.47 & 0.47 & 0.49 & 0.48 \\
\hline Non-indigenous Australian & 0.78 & & 0.74 & \\
\hline Indigenous Australian & 0.02 & & 0.03 & \\
\hline Born overseas / ESC & 0.09 & & 0.09 & \\
\hline Born overseas / NESC & 0.11 & & 0.13 & \\
\hline Less than Year 12 & 0.24 & 0.29 & 0.31 & 0.33 \\
\hline Year 12 & 0.13 & 0.16 & 0.16 & 0.16 \\
\hline Certificate / Diploma & 0.35 & 0.31 & 0.30 & 0.29 \\
\hline Tertiary qualification & 0.28 & 0.25 & 0.22 & 0.22 \\
\hline Father manager & 0.23 & & 0.23 & \\
\hline Father professional & 0.16 & & 0.15 & \\
\hline Father trades & 0.23 & & 0.22 & \\
\hline Father personal service & 0.04 & & 0.04 & \\
\hline Father clerical \& admin & 0.06 & & 0.06 & \\
\hline Father sales & 0.05 & & 0.04 & \\
\hline Father machine operator & 0.10 & & 0.11 & \\
\hline Father labourer & 0.11 & & 0.11 & \\
\hline Father occupation missing & 0.03 & & 0.04 & \\
\hline Father did not complete high school & 0.33 & & 0.25 & \\
\hline Father high school & 0.07 & & 0.07 & \\
\hline Father post-school educ. & 0.52 & & 0.46 & \\
\hline Father education missing & 0.07 & & $0.22^{\mathrm{a}}$ & \\
\hline Openness to experience & 4.28 & 4.26 & 4.26 & 4.25 \\
\hline Conscientiousness & 5.03 & 5.11 & 5.00 & 5.07 \\
\hline Extroversion & 4.45 & 4.42 & 4.49 & 4.45 \\
\hline Agreeableness & 5.37 & 5.41 & 5.36 & 5.39 \\
\hline Emotional stability & 5.10 & 5.17 & 5.08 & 5.14 \\
\hline
\end{tabular}




\begin{tabular}{|c|c|c|c|c|}
\hline \multirow[b]{2}{*}{ Variable } & \multicolumn{2}{|c|}{ Analysis sample } & \multicolumn{2}{|c|}{$\begin{array}{l}\text { Full } 14 \text { wave sample, } \\
15-72 \text { years }\end{array}$} \\
\hline & $\begin{array}{c}\text { First valid } \\
\text { value (except } \\
\text { education - last } \\
\text { valid value) }\end{array}$ & $\begin{array}{c}\text { Pooled } \\
\text { observations, } \\
\text { time-varying }\end{array}$ & $\begin{array}{c}\text { First valid } \\
\text { value (except } \\
\text { education - last } \\
\text { valid value) }\end{array}$ & $\begin{array}{c}\text { Pooled } \\
\text { observations, } \\
\text { time-varying }\end{array}$ \\
\hline $\begin{array}{l}\text { Cognitive ability (backward digits } \\
\text { span) }\end{array}$ & 3.98 & & 3.96 & \\
\hline $\begin{array}{l}\text { Cognitive ability (symbol digit } \\
\text { modalities) }\end{array}$ & 50.14 & & 50.79 & \\
\hline Attitude to financial risk & 3.35 & 3.34 & 3.39 & 3.37 \\
\hline Age $<19$ & 0.14 & 0.03 & 0.22 & 0.08 \\
\hline Age 19-24 & 0.10 & 0.09 & 0.15 & 0.12 \\
\hline Age $25-49$ & 0.59 & 0.55 & 0.49 & 0.48 \\
\hline Age 50-59 & 0.17 & 0.21 & 0.13 & 0.17 \\
\hline Age $60-72$ & & 0.11 & & 0.15 \\
\hline Partnered & 0.62 & 0.67 & 0.56 & 0.63 \\
\hline Long-term health condition & 0.12 & 0.16 & 0.14 & 0.16 \\
\hline Pre-school child & 0.19 & 0.18 & 0.14 & 0.16 \\
\hline School-age child & 0.19 & 0.22 & 0.14 & 0.18 \\
\hline No dependent child aged 18 or less & 0.61 & 0.60 & 0.72 & 0.67 \\
\hline Labour force experience & 14.85 & 20.57 & 14.09 & 20.07 \\
\hline Local unemployment rate & 6.79 & 5.37 & 6.10 & 5.44 \\
\hline
\end{tabular}

Note: Variable definitions are the same as in Table 2 of the article. Data columns 1 and 3 report means based on first available value for each person (or in the case of education, last available value) (as in Table 2 of the article). Columns 2 and 4 report means for the time-varying variables for all pooled observations across all available survey waves.

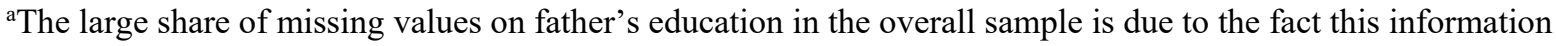
has only been collected since wave 5 so it is unavailable for respondents who dropped out before. 
Table S2. Further details on representativeness as the analysis sample ages

\begin{tabular}{|c|c|c|}
\hline $\begin{array}{l}\text { Labour market outcome state } \\
\text { by (selected) survey wave }\end{array}$ & Analysis sample (\%) & $\begin{array}{c}\text { Full pooled } 14 \text { wave sample, } \\
\text { aged } 15-72 \text { years }(\%)\end{array}$ \\
\hline Wave 1 full-time permanent & 33.97 & 28.55 \\
\hline Wave 1 part-time permanent & 7.15 & 5.89 \\
\hline Wave 1 fixed-term employment & 5.65 & 4.85 \\
\hline Wave 1 casual employment & 14.47 & 13.31 \\
\hline Wave 1 other employed & 12.83 & 12.97 \\
\hline Wave 1 not working & 25.93 & 34.42 \\
\hline Wave 4 full-time permanent & 35.12 & 31.18 \\
\hline Wave 4 part-time permanent & 7.99 & 7.00 \\
\hline Wave 4 fixed-term employment & 5.05 & 4.73 \\
\hline Wave 4 casual employment & 13.72 & 13.23 \\
\hline Wave 4 other employed & 12.98 & 12.33 \\
\hline Wave 4 not working & 25.15 & 31.53 \\
\hline Wave 7 full-time permanent & 37.14 & 33.06 \\
\hline Wave 7 part-time permanent & 8.36 & 7.29 \\
\hline Wave 7 fixed-term employment & 6.04 & 5.62 \\
\hline Wave 7 casual employment & 12.40 & 13.79 \\
\hline Wave 7 other employed & 12.63 & 11.19 \\
\hline Wave 7 not working & 23.42 & 29.06 \\
\hline Wave 10 full-time permanent & 35.92 & 32.13 \\
\hline Wave 10 part-time permanent & 8.99 & 7.75 \\
\hline Wave 10 fixed-term employment & 6.60 & 6.08 \\
\hline Wave 10 casual employment & 10.29 & 13.08 \\
\hline Wave 10 other employed & 12.77 & 10.59 \\
\hline Wave 10 not working & 25.44 & 30.36 \\
\hline Wave 13 full-time permanent & 35.32 & 31.57 \\
\hline Wave 13 part-time permanent & 9.20 & 8.22 \\
\hline Wave 13 fixed-term employment & 5.71 & 5.60 \\
\hline Wave 13 casual employment & 8.40 & 12.66 \\
\hline Wave 13 other employed & 12.24 & 9.99 \\
\hline Wave 13 not working & 29.12 & 31.96 \\
\hline
\end{tabular}


Table S3. Most common sequence types

\begin{tabular}{llc}
\hline Sequence & Description & Frequency \\
\hline All 1s & Persistent full-time permanent & 519 \\
All $6 \mathrm{~s}$ & Persistent not working & 493 \\
All $5 \mathrm{~s}$ & Persistent other employed & 214 \\
$1 \mathrm{~s} \rightarrow 6 \mathrm{~s}$ & Full-time permanent to not employed & 171 \\
$1 \mathrm{~s} \rightarrow 3 \mathrm{~s} \rightarrow 1 \mathrm{~s}$ & Full-time permanent with a spell of fixed-term & 126 \\
$6 \mathrm{~s} \rightarrow 4 \mathrm{~s} \rightarrow 6 \mathrm{~s}$ & Not working with a spell of casual & 91 \\
$5 \mathrm{~s} \rightarrow 6 \mathrm{~s}$ & Other employed to not employed & 87 \\
$6 \mathrm{~s} \rightarrow 7 \mathrm{~s} \rightarrow 6 \mathrm{~s}$ & Not working with a spell of non-response & 82 \\
$1 \mathrm{~s} \rightarrow 7 \mathrm{~s} \rightarrow 1 \mathrm{~s}$ & Full-time permanent with a spell of non-response & 72 \\
$1 \mathrm{~s} \rightarrow 5 \mathrm{~s}$ & Full-time permanent to other employed & 66 \\
$4 \mathrm{~s} \rightarrow 1 \mathrm{~s}$ & Casual to full-time permanent & 52 \\
\hline
\end{tabular}

Key: 1 = Full-time permanent, $2=$ Part-time permanent, $3=$ Fixed-term, $4=$ Casual, $5=$ Other employed, $6=$ Not employed, 7 = Non-response. 
Table S4. OM substitution costs (inverse transition probabilities)

\begin{tabular}{|c|c|c|c|c|c|c|c|}
\hline & FTP & РTP & FXT & CAS & $\mathrm{OE}$ & $\mathrm{NE}$ & NR \\
\hline FTP & & 1.84 & 1.60 & 1.85 & 1.93 & 1.93 & 1.78 \\
\hline РTP & & & 1.84 & 1.85 & 1.96 & 1.90 & 1.94 \\
\hline FXT & & & & 1.89 & 1.95 & 1.92 & 1.94 \\
\hline CAS & & & & & 1.92 & 1.79 & 1.91 \\
\hline $\mathrm{OE}$ & & & & & & 1.91 & 1.90 \\
\hline $\mathrm{NE}$ & & & & & & & 1.82 \\
\hline
\end{tabular}

Notes: The substitution costs between states $x$ and $y$ are defined by: $S C(x, y)=S C(y, x)=2-p(x, y)-p(y, x)$ if $x$ is not equal to $y$, otherwise 0 . Indel costs are set equal to 1 , so indels are never used in place of substitutions.

Key: FTP $=$ Full-time permanent; PTP $=$ Part-time permanent; FXT $=$ Fixed-term; CAS $=$ Casual; OE $=$ Other employed; $\mathrm{NE}=$ Not employed; $\mathrm{NR}=$ Non-response.

Table S5. Alternative OM substitution costs (distance from FT permanent)

\begin{tabular}{|c|c|c|c|c|c|c|c|}
\hline & FTP & РTP & FXT & CAS & $\mathrm{OE}$ & $\mathrm{NE}$ & NR \\
\hline FTP & & 1 & 1 & 2 & 2 & 3 & 2 \\
\hline PTP & & & 1 & 1 & 2 & 2 & 2 \\
\hline FXT & & & & 1 & 2 & 2 & 2 \\
\hline CAS & & & & & 2 & 2 & 2 \\
\hline $\mathrm{OE}$ & & & & & & 2 & 2 \\
\hline $\mathrm{NE}$ & & & & & & & 2 \\
\hline
\end{tabular}

Notes: The substitution costs between states $\mathrm{x}$ and $\mathrm{y}$ are author-defined to reflect a simple conceptualisation of ordinal distance from full-time permanent. So, for example, part-time permanent is treated as being closer to full-time permanent than is casual, but because many casual jobs are part-time, part-time permanent is treated as being equidistant from full-time permanent and casual. Not working is treated as being closer to all non-standard forms of employment than it is to full-time permanent employment. Finally, non-response is treated as equidistant from all other states.

Key: FTP $=$ Full-time permanent; PTP $=$ Part-time permanent; FXT = Fixed-term; CAS $=$ Casual; OE $=$ Other employed; $\mathrm{NE}=$ Not employed; $\mathrm{NR}=$ Non-response. 
Table S6. Sensitivity of classification to substitution costs and indel costs

\begin{tabular}{|c|c|c|c|c|}
\hline & $\begin{array}{l}\text { Original method } \\
\text { (as in Table 4) }\end{array}$ & $\begin{array}{l}\text { User-defined } \\
\text { substitution costs } \\
\text { (as in table S5) }\end{array}$ & $\begin{array}{l}\text { Uniform } \\
\text { substitution costs }\end{array}$ & $\begin{array}{l}\text { IVP substitution } \\
\text { costs, low indel cost }\end{array}$ \\
\hline No. of clusters & 7 & 7 & 8 & 7 \\
\hline Largest cluster & $\begin{array}{l}\text { Persistent full-time } \\
\text { permanent }\end{array}$ & $\begin{array}{l}\text { Persistent full-time } \\
\text { permanent }\end{array}$ & $\begin{array}{l}\text { Persistent full-time } \\
\text { permanent }\end{array}$ & $\begin{array}{l}\text { Persistent full-time } \\
\text { permanent }\end{array}$ \\
\hline $\begin{array}{l}2^{\text {nd }} \text { largest } \\
\text { cluster }\end{array}$ & Not employed & Not employed & Not employed & Not employed \\
\hline $3^{\text {rd }}$ largest & Other employed & Other employed & Other employed & Other employed \\
\hline $4^{\text {th }}$ largest & $\begin{array}{l}\text { Exits from full-time } \\
\text { permanent and } \\
\text { churn }\end{array}$ & $\begin{array}{l}\text { Casual into full- } \\
\text { time permanent }\end{array}$ & $\begin{array}{l}\text { Persistent casual } \\
\text { and casual churn }\end{array}$ & $\begin{array}{l}\text { Persistent casual } \\
\text { and casual churn }\end{array}$ \\
\hline $5^{\text {th }}$ largest & Part-time permanent & Labour market exits & $\begin{array}{l}\text { Casual into full- } \\
\text { time permanent }\end{array}$ & $\begin{array}{l}\text { Exits from full-time } \\
\text { permanent and } \\
\text { churn }\end{array}$ \\
\hline $6^{\text {th }}$ largest & $\begin{array}{l}\text { Casual into full- } \\
\text { time permanent }\end{array}$ & $\begin{array}{l}\text { Persistent casual } \\
\text { and casual churn }\end{array}$ & Part-time permanent & Part-time permanent \\
\hline $7^{\text {th }}$ largest & $\begin{array}{l}\text { Persistent casual } \\
\text { and casual churn }\end{array}$ & Part-time permanent & $\begin{array}{l}\text { Exits from full-time } \\
\text { permanent and } \\
\text { churn }\end{array}$ & $\begin{array}{l}\text { Casual into full- } \\
\text { time permanent }\end{array}$ \\
\hline $8^{\text {th }}$ largest & & & Fixed-term & \\
\hline \multicolumn{5}{|c|}{ Casual bridge cluster } \\
\hline Size & 672 & 888 & 764 & 532 \\
\hline$\%$ waves FTP & 45.3 & 39.9 & 44.2 & 46.9 \\
\hline$\%$ waves PTP & 5.0 & 7.5 & 4.8 & 6.2 \\
\hline$\%$ waves FXT & 8.2 & 7.8 & 7.0 & 6.7 \\
\hline$\%$ waves CAS & 19.7 & 22.9 & 20.0 & 19.2 \\
\hline$\%$ waves OE & 1.5 & 1.3 & 1.6 & 1.7 \\
\hline$\%$ waves NE & 15.7 & 15.8 & 19.1 & 14.4 \\
\hline$\%$ waves NR & 4.6 & 4.8 & 3.4 & 5.0 \\
\hline$\%$ male & 51.8 & 45.8 & 50.0 & 51.7 \\
\hline$\%<$ Year 12 & 15.2 & 14.0 & 13.4 & 14.3 \\
\hline$\%$ aged $<25$ & 65.9 & 67.9 & 67.8 & 65.4 \\
\hline$\%$ aged $50+$ & 1.9 & 2.4 & 2.7 & 2.6 \\
\hline \multicolumn{5}{|c|}{ Casual trap cluster } \\
\hline Size & 651 & 667 & 628 & 963 \\
\hline$\%$ waves FTP & 11.4 & 7.0 & 12.3 & 11.8 \\
\hline$\%$ waves PTP & 8.0 & 16.8 & 10.3 & 11.3 \\
\hline$\%$ waves FXT & 5.7 & 5.7 & 6.5 & 6.5 \\
\hline$\%$ waves CAS & 55.1 & 46.8 & 49.7 & 45.3 \\
\hline$\%$ waves OE & 2.3 & 2.0 & 2.6 & 2.2 \\
\hline$\%$ waves NE & 13.5 & 19.4 & 14.6 & 18.3 \\
\hline$\%$ waves NR & 4.1 & 2.3 & 3.8 & 4.5 \\
\hline$\%$ male & 34.3 & 29.5 & 35.1 & 32.7 \\
\hline$\%<$ Year 12 & 23.2 & 25.2 & 19.9 & 21.9 \\
\hline$\%$ aged $<25$ & 52.4 & 43.9 & 54.3 & 52.1 \\
\hline$\%$ aged $50+$ & 7.2 & 5.1 & 5.2 & 5.4 \\
\hline Overall sample & 8694 & 8694 & 8694 & 8694 \\
\hline
\end{tabular}

Notes: The same sample - the analysis sample - is used in each case. The number of clusters selected in each case is the minimum required to distinguish a coherent casual bridge cluster and a coherent casual trap cluster. Key: FTP $=$ Full-time permanent; PTP $=$ Part-time permanent; FXT $=$ Fixed-term; CAS $=$ Casual; $\mathrm{OE}=$ Other employed; $\mathrm{NE}=$ Not employed; $\mathrm{NR}=$ Non-response; IVP = Inverse probability. 
Table S7. Sensitivity to sample restrictions

\begin{tabular}{|c|c|c|c|c|}
\hline & $\begin{array}{l}\text { Original sample } \\
\text { (as in Table 4) }\end{array}$ & $\geq 19$ only & $<55$ only & $\begin{array}{c}15-59, \\
\geq 6 \text { waves observed }\end{array}$ \\
\hline No. of clusters & 7 & 13 & 10 & 10 \\
\hline Largest cluster & $\begin{array}{l}\text { Persistent full-time } \\
\text { permanent }\end{array}$ & $\begin{array}{l}\text { Persistent full-time } \\
\text { permanent }\end{array}$ & $\begin{array}{l}\text { Persistent full-time } \\
\text { permanent }\end{array}$ & $\begin{array}{l}\text { Persistent full-time } \\
\text { permanent }\end{array}$ \\
\hline $2^{\text {nd }}$ largest cluster & Not employed & Not employed & Not employed & Not employed \\
\hline $3^{\text {rd }}$ largest & Other employed & Other employed & $\begin{array}{l}\text { Not working / } \\
\text { persistent casual } \\
\text { and casual churn }\end{array}$ & $\begin{array}{l}\text { Casual into full- } \\
\text { time permanent }\end{array}$ \\
\hline $4^{\text {th }}$ largest & $\begin{array}{l}\text { Exits from full-time } \\
\text { permanent and } \\
\text { churn }\end{array}$ & $\begin{array}{l}\text { Entry into full-time } \\
\text { permanent from } \\
\text { casual and other } \\
\text { employed }\end{array}$ & $\begin{array}{l}\text { Casual into full- } \\
\text { time permanent }\end{array}$ & $\begin{array}{l}\text { Labour market exits } \\
\text { and labour market } \\
\text { entry from casual }\end{array}$ \\
\hline $5^{\text {th }}$ largest & $\begin{array}{l}\text { Part-time } \\
\text { permanent }\end{array}$ & Labour market exits & Part-time permanent & $\begin{array}{l}\text { Entry to and exit } \\
\text { from full-time } \\
\text { permanent }\end{array}$ \\
\hline $6^{\text {th }}$ largest & $\begin{array}{l}\text { Casual into full- } \\
\text { time permanent }\end{array}$ & Part-time permanent & $\begin{array}{l}\text { Exits from full-time } \\
\text { permanent and } \\
\text { churn }\end{array}$ & $\begin{array}{l}\text { Persistent casual } \\
\text { and casual churn }\end{array}$ \\
\hline $7^{\text {th }}$ largest & $\begin{array}{l}\text { Persistent casual } \\
\text { and casual churn }\end{array}$ & $\begin{array}{l}\text { Exits from full-time } \\
\text { permanent }\end{array}$ & $\begin{array}{l}\text { Labour market exits } \\
\text { and labour market } \\
\text { entry from casual }\end{array}$ & $\begin{array}{l}\text { Entries into and } \\
\text { Exits from other } \\
\text { employed }\end{array}$ \\
\hline $8^{\text {th }}$ largest & & $\begin{array}{l}\text { Other employed } \\
\text { exiting labour } \\
\text { market and churn } \\
\text { through other } \\
\text { employed }\end{array}$ & $\begin{array}{l}\text { Churn through } \\
\text { fixed-term }\end{array}$ & $\begin{array}{l}\text { Part-time } \\
\text { permanent }\end{array}$ \\
\hline $9^{\text {th }}$ largest & & Fixed-term churn & $\begin{array}{l}\text { Part-time permanent } \\
\text { into full-time } \\
\text { permanent }\end{array}$ & Other employed \\
\hline $10^{\text {th }}$ largest & & $\begin{array}{l}\text { Churn between } \\
\text { casual and full-time } \\
\text { permanent }\end{array}$ & & Fixed term churn \\
\hline $11^{\text {th }}$ largest & & $\begin{array}{l}\text { Casual to churning } \\
\text { and churn through } \\
\text { casual }\end{array}$ & & \\
\hline $12^{\text {th }}$ largest & & $\begin{array}{l}\text { Persistent casual } \\
\text { and casual churn }\end{array}$ & & \\
\hline $13^{\text {th }}$ largest & & $\begin{array}{l}\text { Entry to other } \\
\text { employed }\end{array}$ & & \\
\hline \multicolumn{5}{|c|}{ Casual bridge cluster } \\
\hline Size & 672 & 627 & 487 & 962 \\
\hline \% waves FTP & 45.3 & 54.0 & 51.2 & 40.5 \\
\hline$\%$ waves PTP & 5.0 & 3.5 & 4.8 & 5.9 \\
\hline$\%$ waves FXT & 8.2 & 5.2 & 6.6 & 6.4 \\
\hline$\%$ waves CAS & 19.7 & 14.2 & 20.0 & 19.7 \\
\hline$\%$ waves $\mathrm{OE}$ & 1.5 & 8.8 & 1.8 & 1.7 \\
\hline$\%$ waves NE & 15.7 & 11.3 & 13.3 & 17.5 \\
\hline$\%$ waves NR & 4.6 & 3.1 & 2.3 & 8.3 \\
\hline$\%$ male & 51.8 & 58.9 & 53.8 & 51.8 \\
\hline$\%<$ Year 12 & 15.2 & 16.3 & 14.4 & 18.6 \\
\hline$\%$ aged $<25$ & 65.9 & 38.0 & 63.0 & 61.8 \\
\hline$\%$ aged $50+$ & 1.9 & 3.5 & 0.0 & 3.3 \\
\hline \multicolumn{5}{|l|}{ Casual trap cluster } \\
\hline Size & 651 & 281 & 602 & 848 \\
\hline$\%$ waves FTP & 11.4 & 4.3 & 10.8 & 10.4 \\
\hline
\end{tabular}




\begin{tabular}{lccrc}
\hline & $\begin{array}{c}\text { Original sample } \\
\text { (as in Table 4) }\end{array}$ & $\geq 19$ only & $<55$ only & $\begin{array}{c}15-59, \\
\geq 6 \text { waves observed }\end{array}$ \\
\hline \% waves PTP & 8.0 & 11.9 & 5.1 & 5.2 \\
\% waves FXT & 5.7 & 4.5 & 7.3 & 4.3 \\
\% waves CAS & 55.1 & 63.9 & 49.6 & 55.8 \\
\% waves OE & 2.3 & 2.7 & 3.0 & 3.3 \\
\% waves NE & 13.5 & 9.62 & 22.6 & 6.0 \\
\% waves NR & 4.1 & 3.2 & 1.6 & 34.4 \\
\% male & 34.3 & 26.7 & 32.9 & 19.1 \\
\% < Year 12 & 23.2 & 30.6 & 20.6 & 63.9 \\
\% aged $<25$ & 52.4 & 18.2 & 55.8 & 4.8 \\
\% aged 50+ & 7.2 & 12.1 & 0.0 & 10867 \\
Overall sample & 8694 & 7923 & 6455 & \\
\hline
\end{tabular}

Notes: Standard substitution costs and indel costs are used in each case. The number of clusters selected in each case is the minimum required to distinguish a coherent casual bridge cluster and a coherent casual trap cluster. Key: FTP $=$ Full-time permanent; PTP $=$ Part-time permanent FXT $=$ Fixed-term; $\mathrm{CAS}=$ Casual; $\mathrm{OE}=$ Other employed; $\mathrm{NE}=$ Not employed; $\mathrm{NR}=$ Non-response. 
Table S8. Cluster-size sensitivity to dropping those in full-time education

\begin{tabular}{lccc}
\hline Cluster & $\begin{array}{c}\text { Original } \\
\text { sample }\end{array}$ & $\begin{array}{c}\text { Excluding those } \\
\text { i FT education at } \\
\text { any time in first } \\
\text { three observed } \\
\text { years }\end{array}$ & $\begin{array}{c}\text { Excluding those } \\
\text { i FT education at } \\
\text { any time in first } \\
\text { five observed } \\
\text { years }\end{array}$ \\
\hline (1) Persistent full-time permanent & 2315 & 2051 & 2023 \\
(2) Exits from full-time permanent and churn & 1132 & 985 & 967 \\
(3) Casual to full-time permanent & 672 & 233 & 219 \\
(4) Persistent casual and casual churn & 651 & 345 & 331 \\
(5) Part-time permanent & 704 & 603 & 589 \\
(6) Other employed & 1325 & 1233 & 1215 \\
(7) Not working & 1895 & 1570 & 1537 \\
Overall sample & 8694 & 7020 & 6881 \\
\hline
\end{tabular}


Table S9. Splitting the sample by gender and age

\begin{tabular}{|c|c|c|c|c|}
\hline & $\begin{array}{l}\text { Original sample } \\
\text { (as in Table 4) }\end{array}$ & Men & Women & $\begin{array}{l}\text { 15-35 years old at } \\
\text { first wave }\end{array}$ \\
\hline No. of clusters & 7 & 8 & 10 & 7 \\
\hline Largest cluster & $\begin{array}{l}\text { Persistent full-time } \\
\text { permanent }\end{array}$ & $\begin{array}{l}\text { Persistent full-time } \\
\text { permanent }\end{array}$ & $\begin{array}{l}\text { Labour market exits } \\
\text { and Churning in and } \\
\text { out of labour market }\end{array}$ & $\begin{array}{l}\text { Exits from full-time } \\
\text { permanent and } \\
\text { attrition/non- } \\
\text { response }\end{array}$ \\
\hline $\begin{array}{l}2^{\text {nd }} \text { largest } \\
\text { cluster }\end{array}$ & Not employed & $\begin{array}{l}\text { Exits from full-time } \\
\text { permanent and } \\
\text { attrition }\end{array}$ & $\begin{array}{l}\text { Entry to and Exit } \\
\text { from full-time } \\
\text { permanent }\end{array}$ & $\begin{array}{l}\text { Persistent full-time } \\
\text { permanent }\end{array}$ \\
\hline $3^{\text {rd }}$ largest & Other employed & $\begin{array}{l}\text { Entry to and Exit } \\
\text { from Other } \\
\text { employed }\end{array}$ & Not employed & Not employed \\
\hline $4^{\text {th }}$ largest & $\begin{array}{l}\text { Exits from full-time } \\
\text { permanent and } \\
\text { churn }\end{array}$ & $\begin{array}{l}\text { Entry to and Exit } \\
\text { from full-time } \\
\text { permanent with } \\
\text { Churning }\end{array}$ & Part-time permanent & $\begin{array}{l}\text { Persistent casual and } \\
\text { casual churn }\end{array}$ \\
\hline $5^{\text {th }}$ largest & Part-time permanent & $\begin{array}{l}\text { Not employed and } \\
\text { Labour market exits }\end{array}$ & $\begin{array}{l}\text { Casual into full-time } \\
\text { permanent }\end{array}$ & $\begin{array}{l}\text { Casual into full-time } \\
\text { permanent }\end{array}$ \\
\hline $6^{\text {th }}$ largest & $\begin{array}{l}\text { Casual into full-time } \\
\text { permanent }\end{array}$ & $\begin{array}{l}\text { Persistent casual and } \\
\text { casual churn }\end{array}$ & $\begin{array}{l}\text { Churning through } \\
\text { part-time permanent }\end{array}$ & Other employed \\
\hline $7^{\text {th }}$ largest & $\begin{array}{l}\text { Persistent casual and } \\
\text { casual churn }\end{array}$ & Other employed & $\begin{array}{l}\text { Persistent full-time } \\
\text { permanent }\end{array}$ & Part-time permanent \\
\hline $8^{\text {th }}$ largest & & $\begin{array}{l}\text { Casual into full-time } \\
\text { permanent }\end{array}$ & $\begin{array}{l}\text { Persistent casual and } \\
\text { casual churn }\end{array}$ & \\
\hline $9^{\text {th }}$ largest & & & $\begin{array}{l}\text { Labour market exit } \\
\text { from full-time } \\
\text { permanent }\end{array}$ & \\
\hline $10^{\text {th }}$ largest & & & Other employed & \\
\hline \multicolumn{5}{|c|}{ Casual bridge cluster } \\
\hline Size & 672 & 303 & 410 & 420 \\
\hline$\%$ waves FTP & 45.3 & 51.5 & 32.9 & 34.4 \\
\hline$\%$ waves PTP & 5.0 & 2.4 & 6.5 & 4.3 \\
\hline$\%$ waves FXT & 8.2 & 4.3 & 7.7 & 16.9 \\
\hline$\%$ waves CAS & 19.7 & 20.4 & 28.2 & 23.3 \\
\hline$\%$ waves OE & 1.5 & 2.3 & 1.9 & 2.4 \\
\hline$\%$ waves NE & 15.7 & 15.0 & 17.3 & 12.9 \\
\hline$\%$ waves NR & 4.6 & 4.0 & 5.5 & 5.9 \\
\hline$\%$ male & 51.8 & 100.0 & 0.0 & 46.9 \\
\hline$\%<$ Year 12 & 15.2 & 18.5 & 12.2 & 9.5 \\
\hline$\%$ aged $<25$ & 65.9 & 68.7 & 62.9 & 67.4 \\
\hline$\%$ aged $50+$ & 1.9 & 4.0 & 1.5 & 0.0 \\
\hline \multicolumn{5}{|l|}{ Casual trap cluster } \\
\hline Size & 651 & 406 & 306 & 451 \\
\hline \% waves FTP & 11.4 & 14.1 & 4.2 & 11.8 \\
\hline$\%$ waves PTP & 8.0 & 3.2 & 11.5 & 14.9 \\
\hline$\%$ waves FXT & 5.7 & 5.4 & 4.1 & 5.5 \\
\hline$\%$ waves CAS & 55.1 & 42.2 & 59.2 & 33.4 \\
\hline$\%$ waves $\mathrm{OE}$ & 2.3 & 3.0 & 5.3 & 3.5 \\
\hline$\%$ waves NE & 13.5 & 27.6 & 13.9 & 26.2 \\
\hline$\%$ waves NR & 4.1 & 4.7 & 1.9 & 4.8 \\
\hline$\%$ male & 34.3 & 100.0 & 0.0 & 24.0 \\
\hline$\%<$ Year 12 & 23.2 & 23.4 & 31.1 & 23.3 \\
\hline$\%$ aged $<25$ & 52.4 & 62.3 & 27.5 & 48.6 \\
\hline$\%$ aged $50+$ & 7.2 & 12.8 & 9.8 & 0.0 \\
\hline
\end{tabular}




\begin{tabular}{lcccc}
\hline & $\begin{array}{c}\text { Original sample } \\
\text { (as in Table 4) }\end{array}$ & Men & Women & $\begin{array}{c}15-35 \text { years old at } \\
\text { first wave }\end{array}$ \\
\hline Overall sample & 8694 & 4071 & 4621 & 3683 \\
\hline
\end{tabular}

Notes: Standard substitution costs and indel costs are used in each case. The number of clusters selected in each case is the minimum required to distinguish a coherent casual bridge cluster and a coherent casual trap cluster.

Key: FTP = Full-time permanent; PTP $=$ Part-time permanent; FXT $=$ Fixed-term; CAS $=$ Casual; OE $=$ Other employed; $\mathrm{NE}=$ Not employed; $\mathrm{NR}=$ Non-response. 
Table S10. Cluster composition: sample means by cluster

\begin{tabular}{|c|c|c|c|c|c|c|c|c|}
\hline Variable & FT perm & $\begin{array}{l}\text { Exits } \\
\text { from FT } \\
\text { perm }\end{array}$ & $\begin{array}{l}\text { Casual } \\
\text { bridge }\end{array}$ & $\begin{array}{l}\text { Casual } \\
\text { trap }\end{array}$ & $\begin{array}{c}\text { PT } \\
\text { perm }\end{array}$ & $\begin{array}{l}\text { Other } \\
\text { empl'd }\end{array}$ & $\begin{array}{l}\text { Not } \\
\text { empl'd }\end{array}$ & $\begin{array}{c}\text { Over- } \\
\text { all } \\
\text { sample }\end{array}$ \\
\hline Male & 0.69 & 0.37 & 0.52 & 0.34 & 0.09 & 0.64 & 0.30 & 0.47 \\
\hline Non-indigenous Australian & 0.80 & 0.78 & 0.82 & 0.85 & 0.80 & 0.76 & 0.71 & 0.78 \\
\hline Indigenous Australian & 0.01 & 0.01 & 0.03 & 0.02 & 0.02 & 0.01 & 0.05 & 0.02 \\
\hline Born overseas / ESC & 0.09 & 0.11 & 0.05 & 0.05 & 0.10 & 0.12 & 0.09 & 0.09 \\
\hline Born overseas / NESC & 0.10 & 0.09 & 0.11 & 0.08 & 0.09 & 0.11 & 0.15 & 0.11 \\
\hline Less than Year 12 & 0.15 & 0.18 & 0.15 & 0.23 & 0.25 & 0.23 & 0.43 & 0.24 \\
\hline Year 12 & 0.11 & 0.11 & 0.20 & 0.16 & 0.12 & 0.11 & 0.14 & 0.13 \\
\hline Certificate / Diploma & 0.40 & 0.32 & 0.32 & 0.31 & 0.34 & 0.40 & 0.28 & 0.35 \\
\hline Tertiary qualification & 0.33 & 0.39 & 0.32 & 0.30 & 0.30 & 0.26 & 0.15 & 0.28 \\
\hline Father manager & 0.23 & 0.24 & 0.21 & 0.20 & 0.23 & 0.32 & 0.20 & 0.23 \\
\hline Father professional & 0.16 & 0.17 & 0.19 & 0.20 & 0.16 & 0.15 & 0.12 & 0.16 \\
\hline Father trades & 0.24 & 0.23 & 0.20 & 0.22 & 0.24 & 0.22 & 0.22 & 0.23 \\
\hline Father personal service & 0.03 & 0.03 & 0.05 & 0.04 & 0.04 & 0.03 & 0.05 & 0.04 \\
\hline Father clerical \& admin & 0.07 & 0.07 & 0.07 & 0.05 & 0.06 & 0.06 & 0.05 & 0.06 \\
\hline Father sales & 0.05 & 0.04 & 0.04 & 0.07 & 0.05 & 0.05 & 0.04 & 0.05 \\
\hline Father machine operator & 0.11 & 0.11 & 0.09 & 0.11 & 0.11 & 0.07 & 0.13 & 0.10 \\
\hline Father labourer & 0.10 & 0.10 & 0.10 & 0.08 & 0.10 & 0.08 & 0.15 & 0.11 \\
\hline Father occupation missing & 0.02 & 0.02 & 0.06 & 0.04 & 0.02 & 0.01 & 0.05 & 0.03 \\
\hline $\begin{array}{l}\text { Father did not complete } \\
\text { high-school }\end{array}$ & 0.32 & 0.33 & 0.22 & 0.27 & 0.36 & 0.37 & 0.38 & 0.33 \\
\hline Father high school & 0.07 & 0.08 & 0.08 & 0.07 & 0.07 & 0.08 & 0.06 & 0.07 \\
\hline Father post-school educ. & 0.55 & 0.54 & 0.63 & 0.60 & 0.51 & 0.50 & 0.45 & 0.52 \\
\hline Father education missing & 0.06 & 0.05 & 0.07 & 0.06 & 0.07 & 0.05 & 0.12 & 0.07 \\
\hline Openness to experience & 4.24 & 4.29 & 4.40 & 4.31 & 4.09 & 4.40 & 4.23 & 4.28 \\
\hline Conscientiousness & 5.12 & 5.14 & 4.78 & 4.83 & 5.16 & 5.08 & 4.94 & 5.03 \\
\hline Extroversion & 4.40 & 4.50 & 4.58 & 4.58 & 4.50 & 4.52 & 4.34 & 4.45 \\
\hline Agreeableness & 5.28 & 5.44 & 5.29 & 5.41 & 5.56 & 5.34 & 5.40 & 5.37 \\
\hline Neuroticism & 5.11 & 5.14 & 4.91 & 4.98 & 5.20 & 5.24 & 5.01 & 5.10 \\
\hline Big-5 missing & 0.02 & 0.02 & 0.03 & 0.02 & 0.02 & 0.03 & 0.03 & 0.03 \\
\hline $\begin{array}{l}\text { Cognitive ability (backward } \\
\text { digits span) }\end{array}$ & 4.11 & 4.05 & 3.99 & 4.04 & 4.02 & 4.05 & 3.68 & 3.98 \\
\hline BDS missing & 0.08 & 0.05 & 0.08 & 0.09 & 0.07 & 0.10 & 0.09 & 0.08 \\
\hline $\begin{array}{l}\text { Cognitive ability (symbol } \\
\text { digit mod.) }\end{array}$ & 51.60 & 50.68 & 53.82 & 52.69 & 51.61 & 49.26 & 45.94 & 50.14 \\
\hline SDM missing & 0.16 & 0.14 & 0.21 & 0.17 & 0.13 & 0.20 & 0.17 & 0.17 \\
\hline Attitude to financial risk & 3.29 & 3.35 & 3.40 & 3.45 & 3.45 & 3.08 & 3.53 & 3.35 \\
\hline Financial attitude missing & 0.00 & 0.00 & 0.00 & 0.00 & 0.00 & 0.00 & 0.01 & 0.00 \\
\hline Age $<19$ & 0.06 & 0.07 & 0.51 & 0.43 & 0.11 & 0.04 & 0.15 & 0.14 \\
\hline Age 19-24 & 0.13 & 0.14 & 0.15 & 0.09 & 0.07 & 0.05 & 0.07 & 0.10 \\
\hline Age $25-49$ & 0.75 & 0.58 & 0.32 & 0.40 & 0.66 & 0.70 & 0.44 & 0.59 \\
\hline Age $50-59$ & 0.06 & 0.20 & 0.02 & 0.07 & 0.16 & 0.21 & 0.35 & 0.17 \\
\hline Partnered & 0.67 & 0.64 & 0.27 & 0.37 & 0.71 & 0.78 & 0.60 & 0.62 \\
\hline Long-term health condition & 0.05 & 0.07 & 0.07 & 0.09 & 0.09 & 0.09 & 0.29 & 0.12 \\
\hline Pre-school child & 0.22 & 0.12 & 0.14 & 0.15 & 0.27 & 0.24 & 0.19 & 0.19 \\
\hline School-age child & 0.22 & 0.19 & 0.11 & 0.16 & 0.26 & 0.24 & 0.16 & 0.19 \\
\hline $\begin{array}{l}\text { No dependent child aged } 18 \\
\text { or less }\end{array}$ & 0.57 & 0.69 & 0.76 & 0.69 & 0.47 & 0.52 & 0.66 & 0.61 \\
\hline Labour force experience & 15.63 & 16.82 & 5.49 & 8.94 & 14.59 & 20.13 & 14.45 & 14.85 \\
\hline Local unemployment rate & 6.66 & 6.67 & 6.69 & 6.75 & 6.83 & 6.83 & 7.05 & 6.79 \\
\hline
\end{tabular}

Note: For variable definitions see Table 2 of article. 
Table S11. MNL estimates, with sector and occupation dummies (coefficients, standard errors, and relative risk ratios)

\begin{tabular}{|c|c|c|c|c|c|c|}
\hline \multirow[t]{2}{*}{ Variable } & \multicolumn{6}{|c|}{ Cluster } \\
\hline & $\begin{array}{l}\text { Exits from } \\
\text { FT perm }\end{array}$ & $\begin{array}{l}\text { Casual } \\
\text { bridge }\end{array}$ & $\begin{array}{c}\text { Casual } \\
\text { trap }\end{array}$ & PT perm & $\begin{array}{l}\text { Other } \\
\text { empl'd }\end{array}$ & $\begin{array}{c}\text { Not } \\
\text { empl'd }\end{array}$ \\
\hline \multicolumn{7}{|l|}{ Gender (ref. = women $)$} \\
\hline Male & $\begin{array}{l}-1.569^{* * *} \\
(0.098) \\
{[0.208]}\end{array}$ & $\begin{array}{l}-0.991 * * * \\
(0.124) \\
{[0.371]}\end{array}$ & $\begin{array}{l}-1.793 * * * \\
(0.127) \\
{[0.166]}\end{array}$ & $\begin{array}{l}-2.972^{* * *} \\
(0.159) \\
{[0.051]}\end{array}$ & $\begin{array}{l}-0.881 * * * \\
(0.099) \\
{[0.414]}\end{array}$ & $\begin{array}{l}-2.074 * * * \\
(0.108) \\
{[0.126]}\end{array}$ \\
\hline \multicolumn{7}{|c|}{ Origin (ref. $=$ non-indigenous Australian) } \\
\hline Indigenous Australian & $\begin{array}{l}-0.229 \\
(0.348) \\
{[0.795]}\end{array}$ & $\begin{array}{c}0.108 \\
(0.338) \\
{[1.114]}\end{array}$ & $\begin{array}{c}0.093 \\
(0.363) \\
{[1.098]}\end{array}$ & $\begin{array}{c}0.362 \\
(0.355) \\
{[1.437]}\end{array}$ & $\begin{array}{l}-0.251 \\
(0.404) \\
{[0.778]}\end{array}$ & $\begin{array}{l}0.944 * * * \\
(0.272) \\
{[2.571]}\end{array}$ \\
\hline Born overseas / ESC & $\begin{array}{c}0.121 \\
(0.129) \\
{[1.129]}\end{array}$ & $\begin{array}{c}0.034 \\
(0.212) \\
{[1.034]}\end{array}$ & $\begin{array}{l}-0.178 \\
(0.209) \\
{[0.837]}\end{array}$ & $\begin{array}{c}0.153 \\
(0.166) \\
{[1.165]}\end{array}$ & $\begin{array}{c}0.167 \\
(0.123) \\
{[1.182]}\end{array}$ & $\begin{array}{c}0.088 \\
(0.147) \\
{[1.092]}\end{array}$ \\
\hline Born overseas / NESC & $\begin{array}{l}-0.043 \\
(0.135) \\
{[0.958]}\end{array}$ & $\begin{array}{c}0.300^{*} \\
(0.166) \\
{[1.349]}\end{array}$ & $\begin{array}{l}-0.083 \\
(0.183) \\
{[0.920]}\end{array}$ & $\begin{array}{l}-0.064 \\
(0.171) \\
{[0.938]}\end{array}$ & $\begin{array}{c}0.227^{*} \\
(0.128) \\
{[1.255]}\end{array}$ & $\begin{array}{l}0.330^{* *} \\
(0.137) \\
{[1.391]}\end{array}$ \\
\hline \multicolumn{7}{|c|}{ Educational level (ref. = below Year 12) } \\
\hline Year 12 & $\begin{array}{l}-0.051 \\
(0.153) \\
{[0.950]}\end{array}$ & $\begin{array}{c}0.044 \\
(0.181) \\
{[1.045]}\end{array}$ & $\begin{array}{l}-0.369^{* *} \\
(0.179) \\
{[0.691]}\end{array}$ & $\begin{array}{l}-0.241 \\
(0.180) \\
{[0.786]}\end{array}$ & $\begin{array}{l}-0.234 \\
(0.149) \\
{[0.792]}\end{array}$ & $\begin{array}{l}-0.409^{* * *} \\
(0.148) \\
{[0.664]}\end{array}$ \\
\hline Certificate / Diploma & $\begin{array}{l}-0.157 \\
(0.120) \\
{[0.855]}\end{array}$ & $\begin{array}{l}-0.148 \\
(0.153) \\
{[0.862]}\end{array}$ & $\begin{array}{l}-0.530^{* * *} \\
(0.143) \\
{[0.588]}\end{array}$ & $\begin{array}{l}-0.298^{* *} \\
(0.139) \\
{[0.742]}\end{array}$ & $\begin{array}{l}-0.337^{* * *} \\
(0.112) \\
{[0.714]}\end{array}$ & $\begin{array}{l}-0.648^{* * *} \\
(0.115) \\
{[0.523]}\end{array}$ \\
\hline Tertiary qualification & $\begin{array}{c}0.065 \\
(0.142) \\
{[1.067]}\end{array}$ & $\begin{array}{c}0.123 \\
(0.179) \\
{[1.131]}\end{array}$ & $\begin{array}{l}-0.290^{*} \\
(0.171) \\
{[0.748]}\end{array}$ & $\begin{array}{l}-0.344^{* *} \\
(0.169) \\
{[0.709]}\end{array}$ & $\begin{array}{l}-0.577 * * * \\
(0.139) \\
{[0.562]}\end{array}$ & $\begin{array}{l}-0.776^{* * *} \\
(0.147) \\
{[0.460]}\end{array}$ \\
\hline \multicolumn{7}{|c|}{ Father's educational level (ref. = did not complete high-school) } \\
\hline Father high school & $\begin{array}{c}0.004 \\
(0.160) \\
{[1.004]}\end{array}$ & $\begin{array}{c}0.130 \\
(0.203) \\
{[1.139]}\end{array}$ & $\begin{array}{l}-0.120 \\
(0.214) \\
{[0.887]}\end{array}$ & $\begin{array}{l}-0.030 \\
(0.200) \\
{[0.970]}\end{array}$ & $\begin{array}{c}0.048 \\
(0.157) \\
{[1.049]}\end{array}$ & $\begin{array}{c}0.010 \\
(0.176) \\
{[1.010]}\end{array}$ \\
\hline Father post-school educ. & $\begin{array}{l}-0.064 \\
(0.095) \\
{[0.938]}\end{array}$ & $\begin{array}{c}0.209 \\
(0.129) \\
{[1.232]}\end{array}$ & $\begin{array}{c}0.074 \\
(0.126) \\
{[1.077]}\end{array}$ & $\begin{array}{l}-0.150 \\
(0.118) \\
{[0.861]}\end{array}$ & $\begin{array}{l}-0.139 \\
(0.093) \\
{[0.871]}\end{array}$ & $\begin{array}{c}0.023 \\
(0.102) \\
{[1.023]}\end{array}$ \\
\hline Openness to experience & $\begin{array}{c}0.081^{*} \\
(0.042) \\
{[1.084]}\end{array}$ & $\begin{array}{l}0.181^{* * *} \\
(0.055) \\
{[1.198]}\end{array}$ & $\begin{array}{l}0.156^{* * *} \\
(0.055) \\
{[1.168]}\end{array}$ & $\begin{array}{l}-0.003 \\
(0.052) \\
{[0.997]}\end{array}$ & $\begin{array}{l}0.287 * * * \\
(0.043) \\
{[1.332]}\end{array}$ & $\begin{array}{l}0.312^{* * *} \\
(0.046) \\
{[1.366]}\end{array}$ \\
\hline Conscientiousness & $\begin{array}{l}-0.089 * * \\
(0.041) \\
{[0.914]}\end{array}$ & $\begin{array}{l}-0.161 * * * \\
(0.053) \\
{[0.851]}\end{array}$ & $\begin{array}{l}-0.223 * * * \\
(0.053) \\
{[0.800]}\end{array}$ & $\begin{array}{l}-0.100^{*} \\
(0.051) \\
{[0.905]}\end{array}$ & $\begin{array}{l}-0.183 * * * \\
(0.042) \\
{[0.832]}\end{array}$ & $\begin{array}{l}-0.212 * * * \\
(0.044) \\
{[0.809]}\end{array}$ \\
\hline Extroversion & $\begin{array}{l}-0.007 \\
(0.038) \\
{[0.993]}\end{array}$ & $\begin{array}{c}0.034 \\
(0.049) \\
{[1.035]}\end{array}$ & $\begin{array}{l}-0.000 \\
(0.049) \\
{[1.000]}\end{array}$ & $\begin{array}{l}-0.093^{* *} \\
(0.046) \\
{[0.911]}\end{array}$ & $\begin{array}{c}0.053 \\
(0.038) \\
{[1.055]}\end{array}$ & $\begin{array}{l}-0.074 * \\
(0.041) \\
{[0.929]}\end{array}$ \\
\hline Agreeableness & $\begin{array}{l}-0.048 \\
(0.050) \\
{[0.954]}\end{array}$ & $\begin{array}{l}-0.025 \\
(0.063) \\
{[0.975]}\end{array}$ & $\begin{array}{c}0.043 \\
(0.064) \\
{[1.044]}\end{array}$ & $\begin{array}{l}-0.024 \\
(0.064) \\
{[0.976]}\end{array}$ & $\begin{array}{l}-0.045 \\
(0.049) \\
{[0.956]}\end{array}$ & $\begin{array}{l}-0.147 * * * \\
(0.052) \\
{[0.864]}\end{array}$ \\
\hline
\end{tabular}




\begin{tabular}{|c|c|c|c|c|c|c|}
\hline \multirow[t]{2}{*}{ Variable } & \multicolumn{6}{|c|}{ Cluster } \\
\hline & $\begin{array}{l}\text { Exits from } \\
\text { FT perm }\end{array}$ & $\begin{array}{l}\text { Casual } \\
\text { bridge }\end{array}$ & $\begin{array}{l}\text { Casual } \\
\text { trap }\end{array}$ & PT perm & $\begin{array}{l}\text { Other } \\
\text { empl'd }\end{array}$ & $\begin{array}{l}\text { Not } \\
\text { empl'd }\end{array}$ \\
\hline Emotional stability & $\begin{array}{c}0.003 \\
(0.041) \\
{[1.003]}\end{array}$ & $\begin{array}{c}0.005 \\
(0.051) \\
{[1.005]}\end{array}$ & $\begin{array}{c}0.047 \\
(0.052) \\
{[1.048]}\end{array}$ & $\begin{array}{c}0.062 \\
(0.051) \\
{[1.064]}\end{array}$ & $\begin{array}{l}0.150^{* * *} \\
(0.041) \\
{[1.162]}\end{array}$ & $\begin{array}{c}0.045 \\
(0.043) \\
{[1.046]}\end{array}$ \\
\hline $\begin{array}{l}\text { Cognitive ability (backward } \\
\text { digits span) }\end{array}$ & $\begin{array}{l}-0.033 \\
(0.029) \\
{[0.968]}\end{array}$ & $\begin{array}{l}-0.057 \\
(0.038) \\
{[0.945]}\end{array}$ & $\begin{array}{l}-0.002 \\
(0.038) \\
{[0.998]}\end{array}$ & $\begin{array}{l}-0.029 \\
(0.036) \\
{[0.972]}\end{array}$ & $\begin{array}{l}-0.003 \\
(0.029) \\
{[0.997]}\end{array}$ & $\begin{array}{l}-0.070^{* *} \\
(0.032) \\
{[0.932]}\end{array}$ \\
\hline $\begin{array}{l}\text { Cognitive ability (symbol } \\
\text { digit modalities) }\end{array}$ & $\begin{array}{l}-0.015 * * * \\
(0.004) \\
{[0.985]}\end{array}$ & $\begin{array}{l}-0.005 \\
(0.006) \\
{[0.995]}\end{array}$ & $\begin{array}{l}-0.015^{* * *} \\
(0.006) \\
{[0.985]}\end{array}$ & $\begin{array}{l}-0.014 * * \\
(0.005) \\
{[0.987]}\end{array}$ & $\begin{array}{l}-0.011^{* *} \\
(0.005) \\
{[0.989]}\end{array}$ & $\begin{array}{l}-0.030 * * * \\
(0.005) \\
{[0.971]}\end{array}$ \\
\hline Attitude to financial risk & $\begin{array}{l}-0.012 \\
(0.058) \\
{[0.988]}\end{array}$ & $\begin{array}{l}-0.004 \\
(0.070) \\
{[0.996]}\end{array}$ & $\begin{array}{c}0.017 \\
(0.073) \\
{[1.017]}\end{array}$ & $\begin{array}{l}-0.024 \\
(0.074) \\
{[0.976]}\end{array}$ & $\begin{array}{l}-0.411 * * * \\
(0.052) \\
{[0.663]}\end{array}$ & $\begin{array}{c}0.027 \\
(0.061) \\
{[1.027]}\end{array}$ \\
\hline \multicolumn{7}{|l|}{ Age $($ ref.$=25-49$ years $)$} \\
\hline$<19$ years & $\begin{array}{l}0.424 * * \\
(0.197) \\
{[1.528]}\end{array}$ & $\begin{array}{l}1.868^{* * *} \\
(0.221) \\
{[6.474]}\end{array}$ & $\begin{array}{l}2.186^{* * *} \\
(0.227) \\
{[8.900]}\end{array}$ & $\begin{array}{l}1.152 * * * \\
(0.234) \\
{[3.164]}\end{array}$ & $\begin{array}{l}-0.132 \\
(0.220) \\
{[0.876]}\end{array}$ & $\begin{array}{l}1.148^{* * *} \\
(0.187) \\
{[3.153]}\end{array}$ \\
\hline $19-24$ years & $\begin{array}{l}0.304^{* *} \\
(0.145) \\
{[1.355]}\end{array}$ & $\begin{array}{c}0.218 \\
(0.198) \\
{[1.244]}\end{array}$ & $\begin{array}{c}0.062 \\
(0.216) \\
{[1.064]}\end{array}$ & $\begin{array}{l}-0.281 \\
(0.204) \\
{[0.755]}\end{array}$ & $\begin{array}{l}-0.744 * * * \\
(0.176) \\
{[0.475]}\end{array}$ & $\begin{array}{l}-0.428^{* *} \\
(0.167) \\
{[0.652]}\end{array}$ \\
\hline $50-59$ years & $\begin{array}{l}1.387^{* * *} \\
(0.160) \\
{[4.003]}\end{array}$ & $\begin{array}{l}0.855^{* *} \\
(0.349) \\
{[2.351]}\end{array}$ & $\begin{array}{l}1.234^{* * *} \\
(0.243) \\
{[3.434]}\end{array}$ & $\begin{array}{l}1.789^{* * *} \\
(0.197) \\
{[5.985]}\end{array}$ & $\begin{array}{l}1.193 * * * \\
(0.159) \\
{[3.298]}\end{array}$ & $\begin{array}{l}3.028^{* * *} \\
(0.174) \\
{[20.649]}\end{array}$ \\
\hline Partnered & $\begin{array}{c}0.047 \\
(0.097) \\
{[1.048]}\end{array}$ & $\begin{array}{l}-0.406^{* * *} \\
(0.148) \\
{[0.666]}\end{array}$ & $\begin{array}{l}-0.202 \\
(0.140) \\
{[0.817]}\end{array}$ & $\begin{array}{c}0.324^{* *} \\
(0.127) \\
{[1.382]}\end{array}$ & $\begin{array}{l}0.245^{* *} \\
(0.104) \\
{[1.278]}\end{array}$ & $\begin{array}{c}0.227 * * \\
(0.110) \\
{[1.255]}\end{array}$ \\
\hline Long-term health condition & $\begin{array}{l}0.421 * * * \\
(0.159) \\
{[1.524]}\end{array}$ & $\begin{array}{l}0.697 * * * \\
(0.198) \\
{[2.007]}\end{array}$ & $\begin{array}{l}0.931 * * * \\
(0.183) \\
{[2.538]}\end{array}$ & $\begin{array}{l}0.864 * * * \\
(0.180) \\
{[2.374]}\end{array}$ & $\begin{array}{l}0.624 * * * \\
(0.152) \\
{[1.867]}\end{array}$ & $\begin{array}{l}1.561 * * * \\
(0.142) \\
{[4.761]}\end{array}$ \\
\hline \multicolumn{7}{|c|}{ Youngest child (ref. $=$ no child below 18 years in income unit) } \\
\hline Pre-school child & $\begin{array}{l}-0.469 * * * \\
(0.122) \\
{[0.626]}\end{array}$ & $\begin{array}{l}0.714^{* * *} \\
(0.173) \\
{[2.042]}\end{array}$ & $\begin{array}{l}0.630^{* * *} \\
(0.166) \\
{[1.878]}\end{array}$ & $\begin{array}{l}0.651^{* * *} \\
(0.138) \\
{[1.918]}\end{array}$ & $\begin{array}{l}0.263^{* *} \\
(0.108) \\
{[1.301]}\end{array}$ & $\begin{array}{l}0.559 * * * \\
(0.123) \\
{[1.749]}\end{array}$ \\
\hline School-age child & $\begin{array}{l}-0.250^{* *} \\
(0.109) \\
{[0.779]}\end{array}$ & $\begin{array}{l}0.637 * * * \\
(0.185) \\
{[1.892]}\end{array}$ & $\begin{array}{l}0.464 * * * \\
(0.162) \\
{[1.591]}\end{array}$ & $\begin{array}{l}0.327^{* *} \\
(0.135) \\
{[1.387]}\end{array}$ & $\begin{array}{c}0.116 \\
(0.107) \\
{[1.123]}\end{array}$ & $\begin{array}{l}-0.079 \\
(0.127) \\
{[0.924]}\end{array}$ \\
\hline Labour force experience & $\begin{array}{c}0.003 \\
(0.006) \\
{[1.003]}\end{array}$ & $\begin{array}{l}-0.042 * * * \\
(0.010) \\
{[0.959]}\end{array}$ & $\begin{array}{c}0.000 \\
(0.009) \\
{[1.000]}\end{array}$ & $\begin{array}{l}-0.014 * \\
(0.008) \\
{[0.986]}\end{array}$ & $\begin{array}{c}0.008 \\
(0.006) \\
{[1.008]}\end{array}$ & $\begin{array}{l}-0.048 * * * \\
(0.007) \\
{[0.953]}\end{array}$ \\
\hline Local unemployment rate & $\begin{array}{c}0.014 \\
(0.017) \\
{[1.014]}\end{array}$ & $\begin{array}{l}0.054 * * \\
(0.021) \\
{[1.056]}\end{array}$ & $\begin{array}{l}0.045^{* *} \\
(0.021) \\
{[1.046]}\end{array}$ & $\begin{array}{c}0.020 \\
(0.021) \\
{[1.021]}\end{array}$ & $\begin{array}{l}0.042 * * \\
(0.017) \\
{[1.043]}\end{array}$ & $\begin{array}{l}0.059 * * * \\
(0.018) \\
{[1.061]}\end{array}$ \\
\hline Constant & 0.771 & $-1.921 * *$ & -0.321 & 0.832 & $2.242 * * *$ & $2.648^{* * *}$ \\
\hline
\end{tabular}

Notes:

$\mathrm{N}=8688$.

The base category is cluster 1 (persistent full-time permanent).

Figures in curved parentheses are robust standard errors; figures in square parentheses are relative risk ratios.

$*, * *$ and ${ }^{* * *}$ denote significance at the $10 \%, 5 \%$ and $1 \%$ levels, respectively. 
Also included, but not reported, are 7 dummies for respondent's occupation and 18 dummies for respondent's industry as well as 8 dummies for father's occupation at age 14. To preserve sample size, missing values for the personality, cognitive ability, and attitude to financial risk variables are set to their respective sample mean values and dummy variables identifying cases with missing observations on each of these variables included in the estimation. Additionally, the model includes a dummy variable for missing information on father's educational level as well as an indicator for persons who are never observed working (and thus lack information on occupation and industry). 
Figure S1. Dendrogram, standard sample (Ward's agglomerative method)

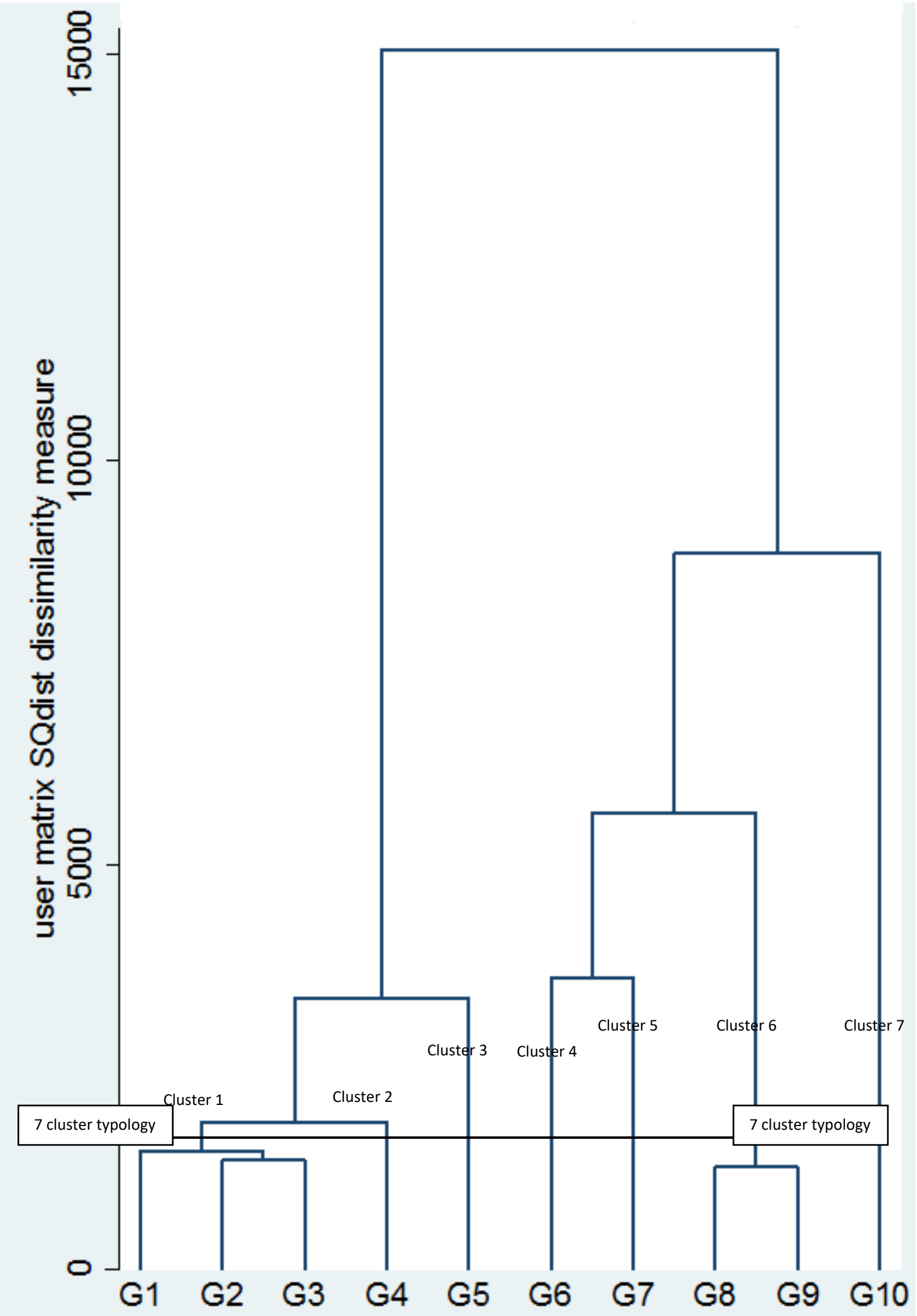


Figure S2. Typology of labour market pathways (7 clusters): sequence index plots

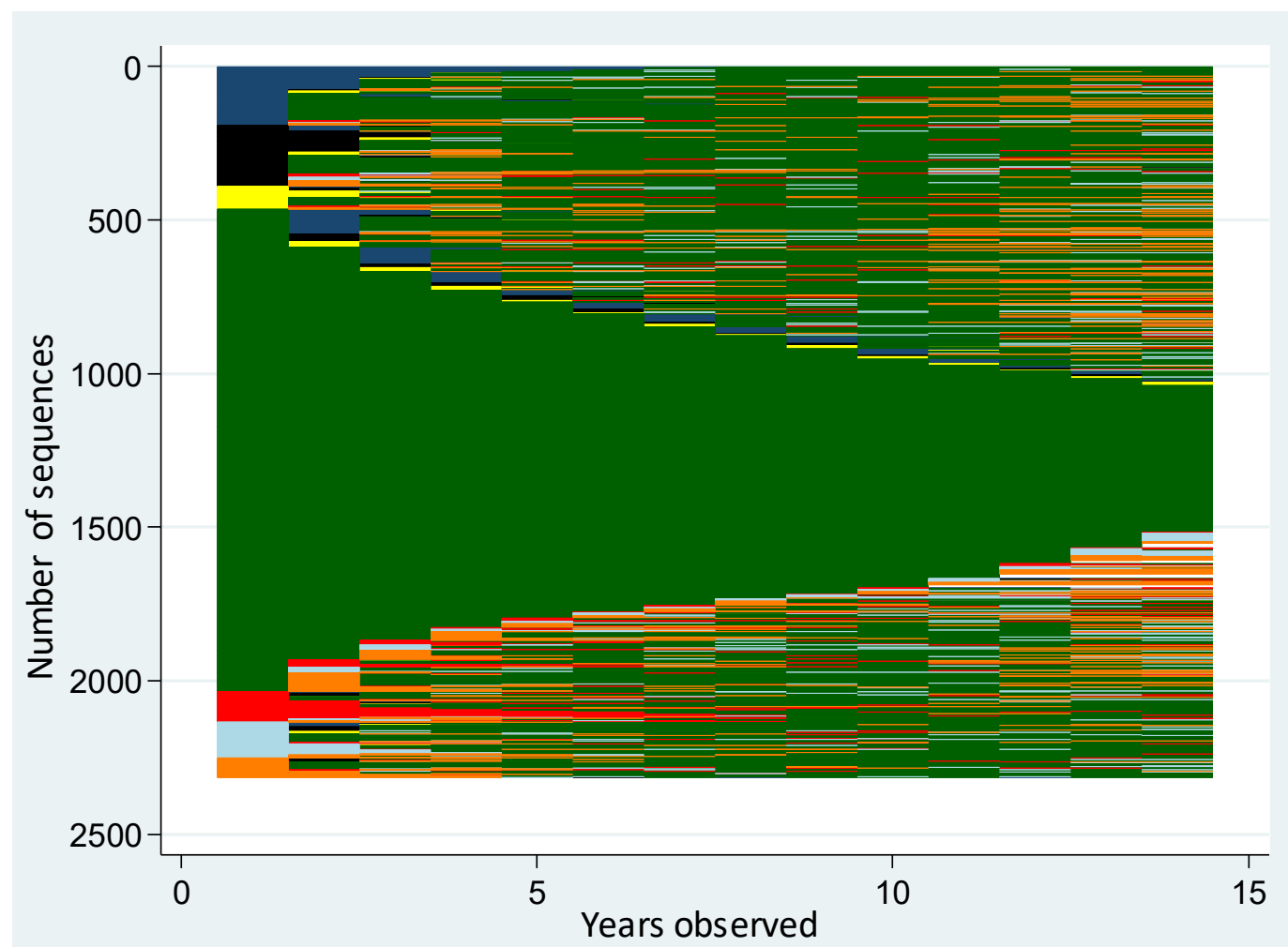

\begin{tabular}{|l|}
\hline$\square$ \\
\hline Fixed term \\
casual \\
PT permanent \\
FT permanent \\
Other employed \\
Not working \\
Non-respondent \\
\hline
\end{tabular}

Group 1: Persistent full-time permanent

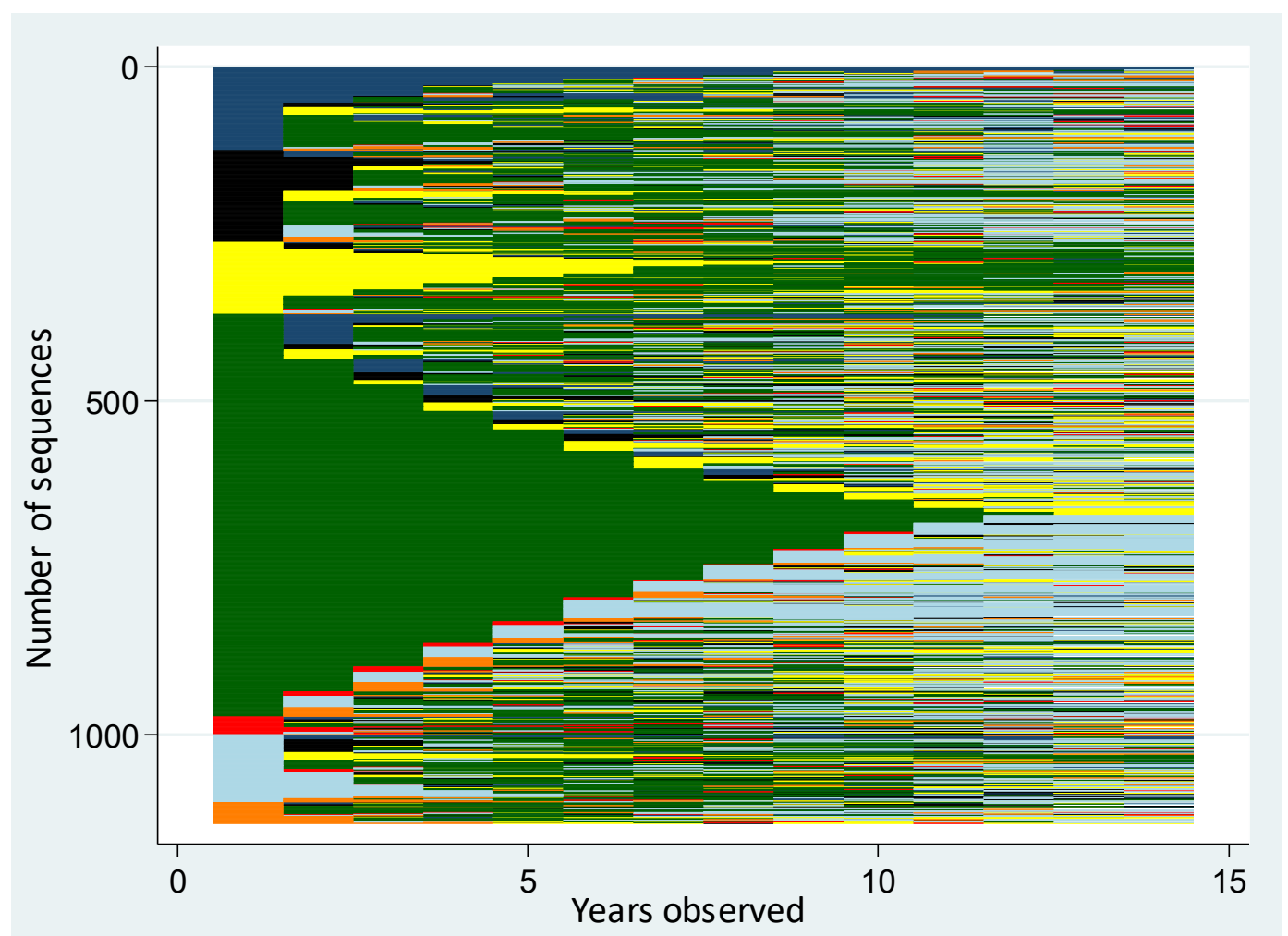

Group 2: Exits from full-time permanent and churn 


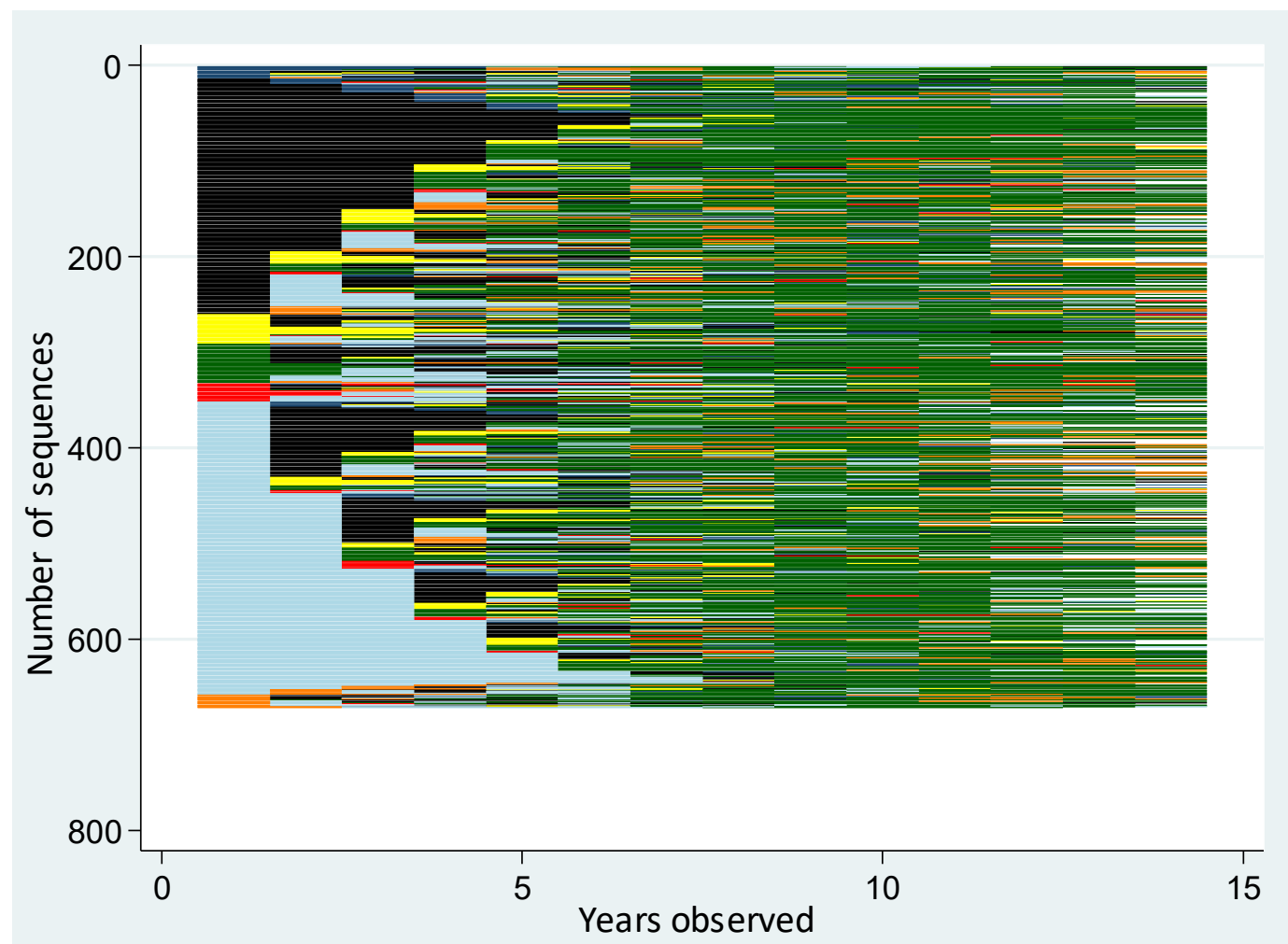

Group 3: Casual to full-time permanent

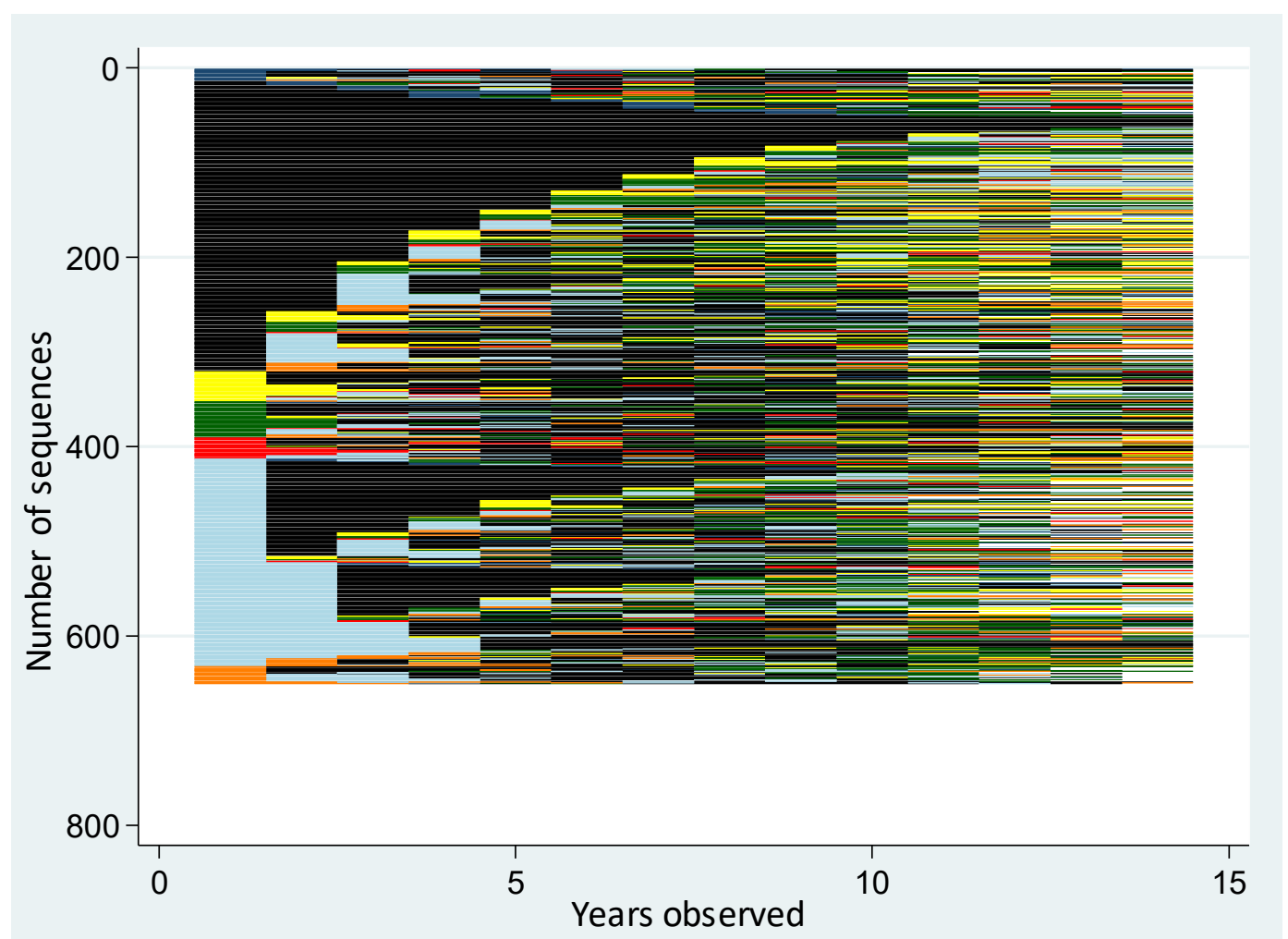

Group 4: Persistent casual and casual churn 


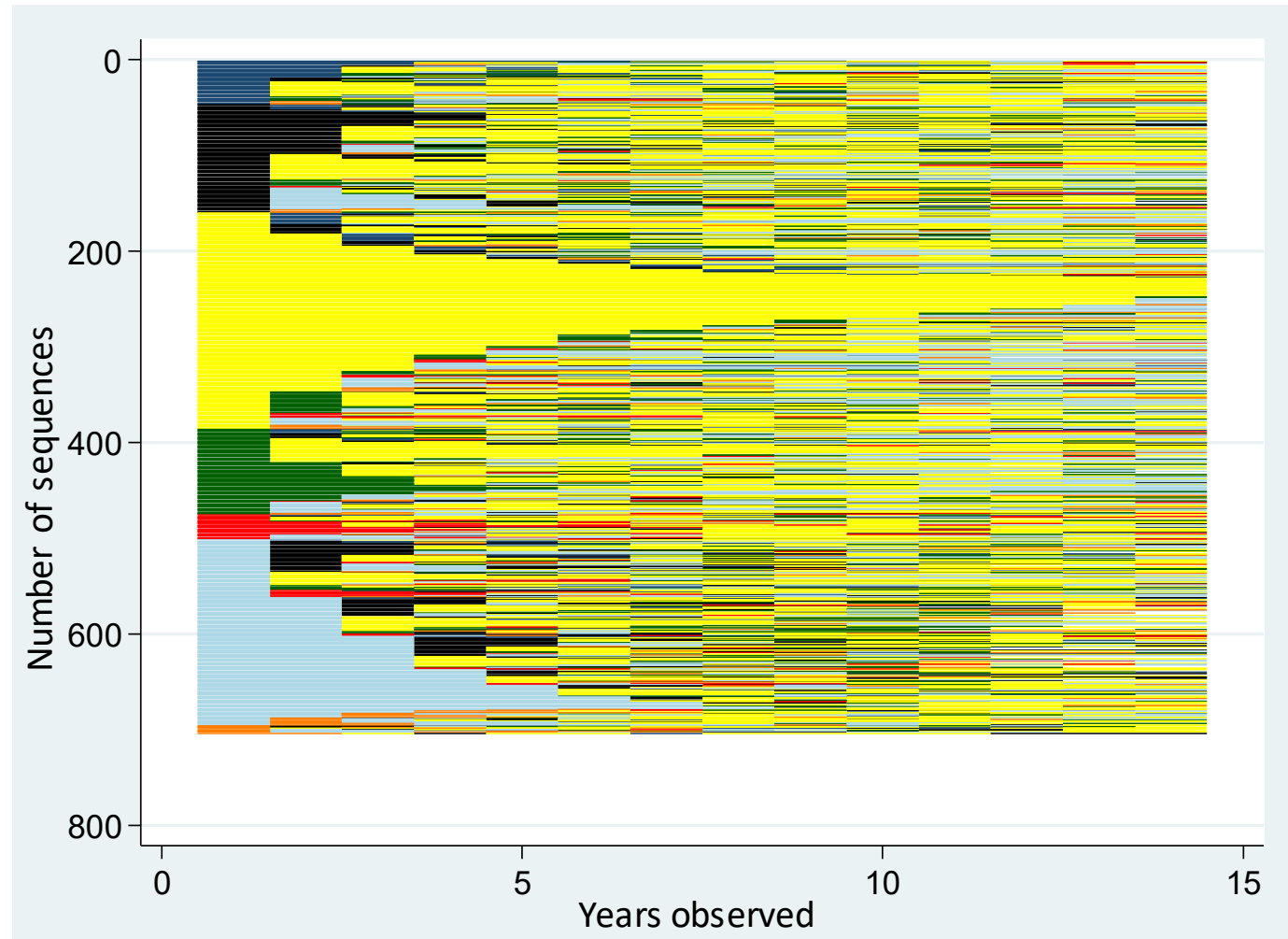

Group 5: Part-time permanent

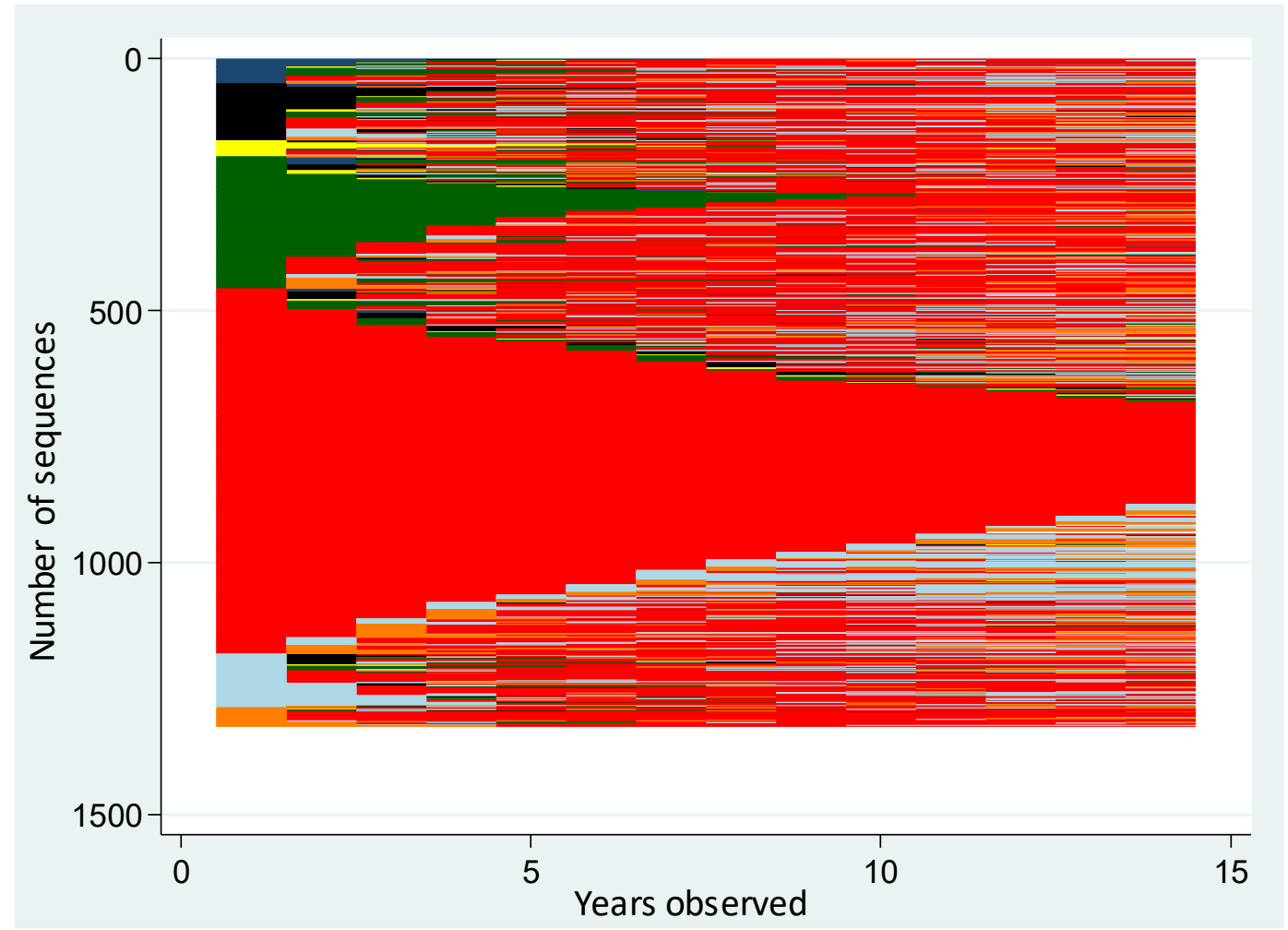

Group 6: Other employed 


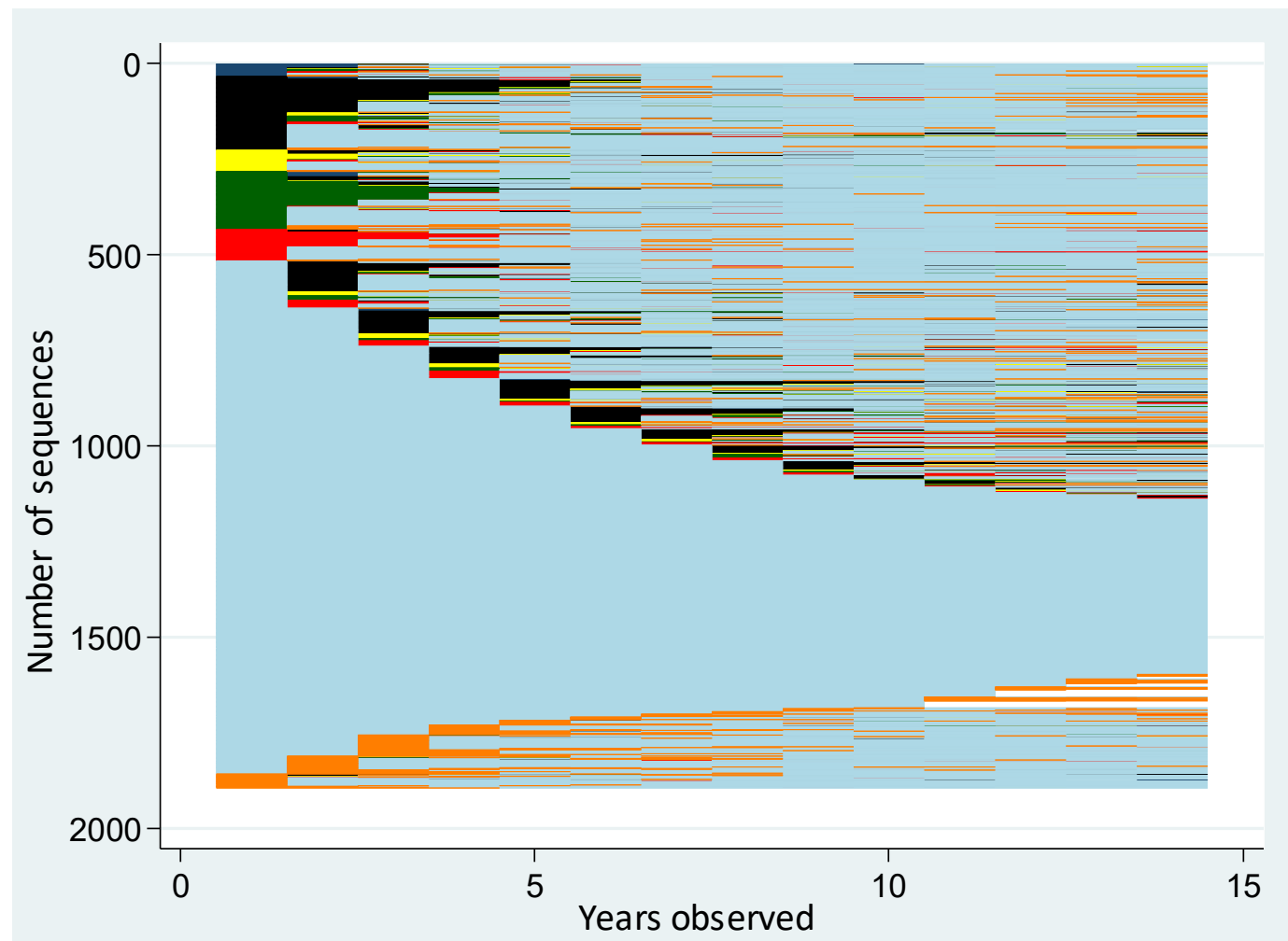

\section{Group 7: Not working}

Notes:

These plots consist of a horizontal line for each sequence, by cluster, with different labour market states within a sequence represented by different colours as defined in the key above. The vertical axis gives the number of individuals in each cluster, with sequences sorted along the vertical axis using the default algorithm in sq.ado. 